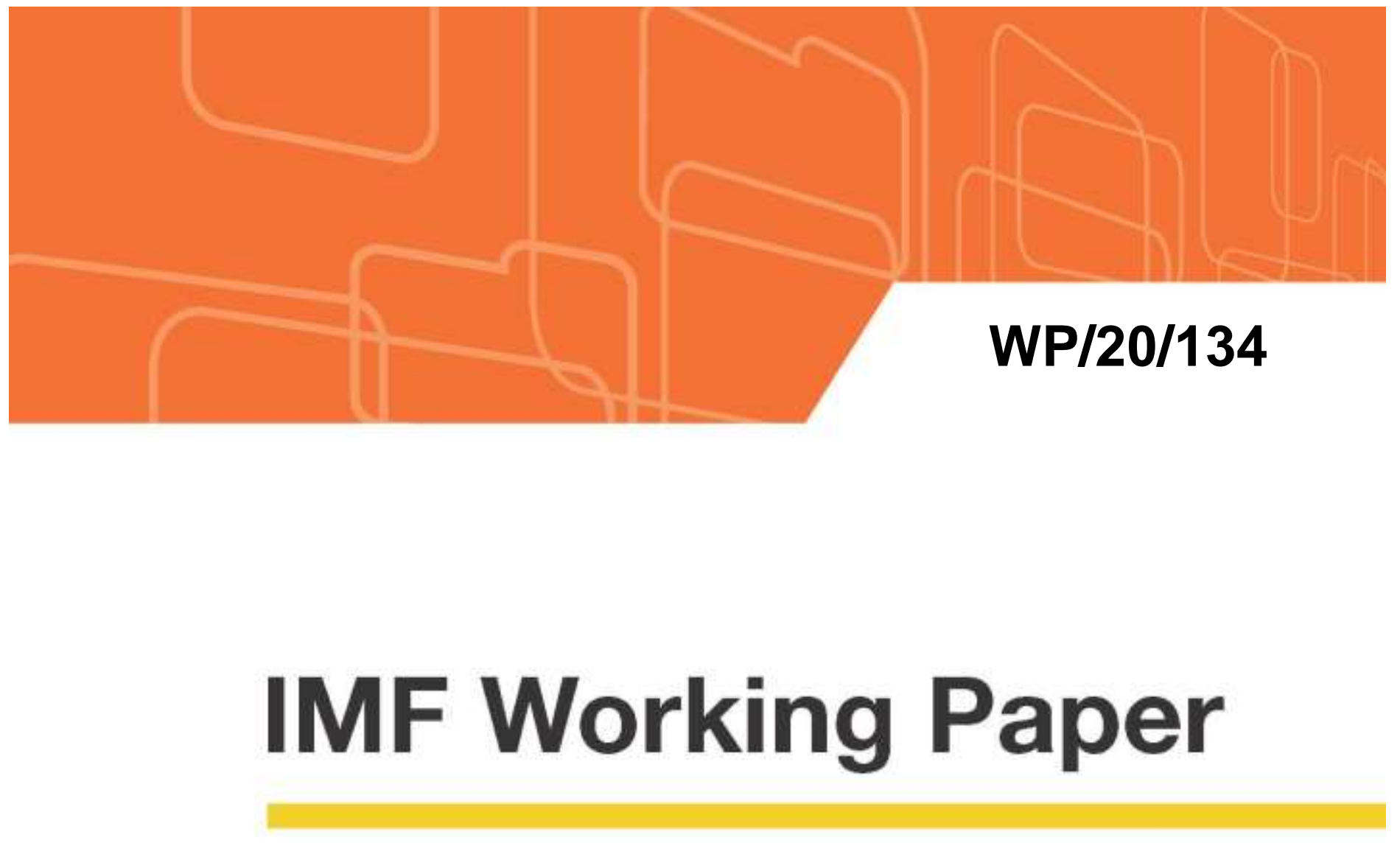

\title{
The Effectiveness of Borrower-Based Macroprudential Measures: A Quantitative Analysis for Slovakia
}

by Pavol Jurča, Ján Klacso, Eugen Tereanu, Marco Forletta, Marco Gross

IMF Working Papers describe research in progress by the author(s) and are published to elicit comments and to encourage debate. The views expressed in IMF Working Papers are those of the author(s) and do not necessarily represent the views of the IMF, its Executive Board, or IMF management. 


\title{
IMF Working Paper
}

Monetary and Capital Markets Department

\section{The Effectiveness of Borrower-Based Macroprudential Measures: A Quantitative Analysis for Slovakia}

\author{
Prepared by Pavol Jurča, Ján Klacso, Eugen Tereanu, Marco Forletta, Marco Gross \\ Authorized for distribution by Martin Čihák
}

June 2020

Disclaimer: This document was prepared before COVID-19 became a global pandemic and resulted in unprecedented economic strains. It, therefore, does not reflect the implications of these developments and related policy priorities. We direct you to the IMF Covid-19 page that includes staff recommendations with regard to the COVID-19 global outbreak.

IMF Working Papers describe research in progress by the author(s) and are published to elicit comments and to encourage debate. The views expressed in IMF Working Papers are those of the author(s) and do not necessarily represent the views of the IMF, its Executive Board, or IMF management.

\begin{abstract}
We develop a semi-structural quantitative framework that combines micro and macroeconomic data to assess the effectiveness of combinations of borrower-based macroprudential measures in Slovakia. We expand on the integrated dynamic household balance sheet model of Gross and Población (2017) by introducing an endogenous loan granting feature, in turn to quantify the potential (ex-ante) impact of macroprudential measures on resilience parameters, compared with a counterfactual no-policy scenario, under adverse macroeconomic conditions. We conclude that (1) borrower-based measures can noticeably improve household and bank resilience to macroeconomic downturns, in particular when multiple measures are applied; (2) those measures tend to complement each other, as the impact of individual instruments is transmitted via different channels; and (3) the resilience benefits are more sizeable if the measures effectively limit the accumulation of risks before an economic downturn occurs, suggesting that an early, preemptive implementation of borrower-based measures is indeed warranted.
\end{abstract}

JEL Classification Numbers: C33, E58, G18.

Keywords: Borrower-based macroprudential policy, household micro data, macrofinancial linkages.

Authors'email addresses: pavol.jurca@nbs.sk,jan.klacso@nbs.sk, eugen.tereanu@ecb.europa.eu,marco.forletta@ecb.europa.eu,mgross@imf.org

* The authors gratefully acknowledge comments from participants at the 13th Financial Stability Seminar of the National Bank of Slovakia, an IMF internal seminar organized by the Monetary and Capital Markets Department, and the joint ECB/Banca d'Italia Research Workshop on Macroprudential Policies. In particular, the authors would like to thank Adrian Alter, Ahmad El Ashram, Lucyna Gornicka, Niamh Hallissey, Erlend Nier, Thordvardur Tjoervi Olafsson, and Laura Valderrama for their detailed comments and suggestions, and Marco Lo Duca and Marek Ličák for their guidance and support. 


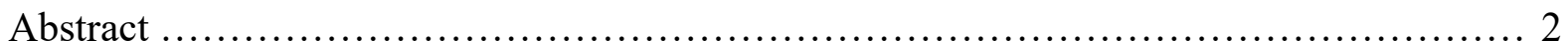

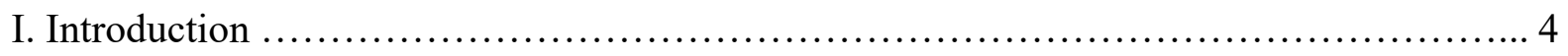

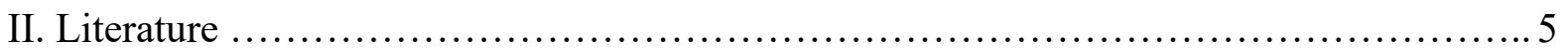

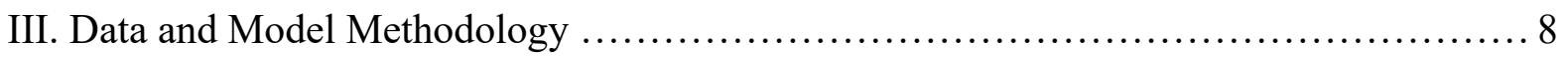

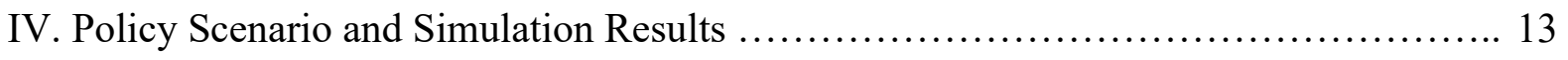

V. The Interaction of Borrower-Based and Capital-Based Measures .................... 18

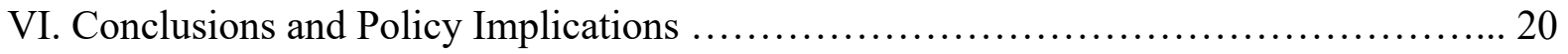

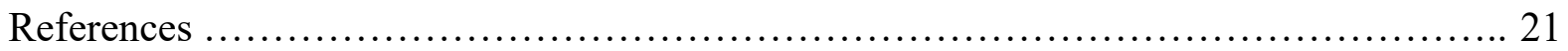

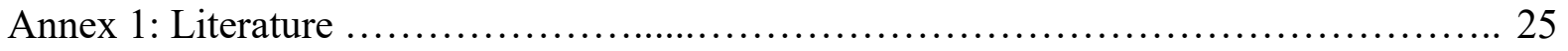

Annex 2 Additional Model Details ............................................... 26

Annex 3: Reported versus Imputed Current House Price Values ...................... 37 


\section{INTRODUCTION}

\section{Borrower-based measures have been activated and gradually tightened in Slovakia since late 2014 to address the buildup of systemic risk related to strong credit growth and household indebtedness (Figure 1). The original National Bank of Slovakia (NBS) recommendation - to establish a comprehensive framework for prudential lending practices - subsequently became legally binding and was twice amended to extend the scope and increase effectiveness in addressing financial stability risks. ${ }^{1}$ The data and quantitative toolkit used to analyze the impact of the measures have been progressively enhanced as the risks and policy mix evolved over time. As borrower-based measures have become increasingly focused on addressing financial stability risks stemming from the excessive dynamic of household debt, there has been a growing need to quantify the impact of the combination of borrower-based measures on household and bank resilience.}

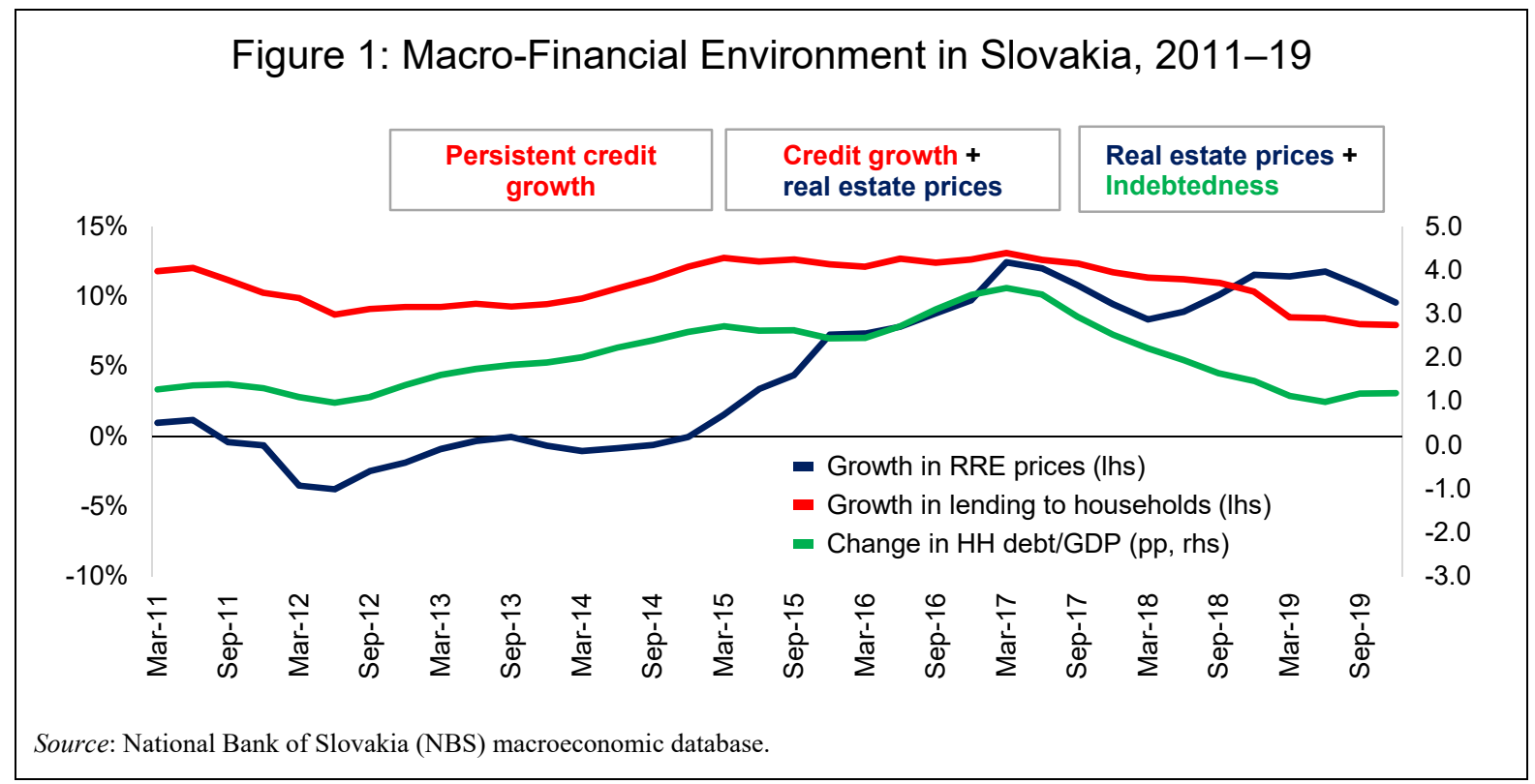

We employ a modular framework to quantify the change in the resilience of households and banks, resulting from the tightening of borrower-based measures, under an adverse macroeconomic scenario., ${ }^{2,3}$ The semi-structural micro-macro approach of Gross and Población (2017) is adapted to the Slovak context. Micro modules for employment and new lending are combined with a structural error correction model (ECM)-based macro module into a dynamic household balance sheet simulator. A rule for default detection, based on the households' capacity to service their mortgage debt payments, enables the calculation

\footnotetext{
1 For additional details on the evolution of the risk environment and the rationale for macroprudential policy measures in Slovakia, see the selected issues paper (https://www.imf.org/en/Publications/CR/Issues/2018/07/26/Slovak-Republic-Selected-Issues-46123) on credit growth and macroprudential policies of the Slovak Republic (IMF AIV 2018).

${ }^{2}$ All analysis presented in this paper was conducted on pre-Covid-19 data.

${ }^{3}$ The framework also entails the estimation of the risk profile of new lending during periods of exuberant credit growth. As losses materialize only with a lag when an economic downturn occurs, it is important to be able to estimate risk parameters (PDs, LGDs, expected losses) for new lending to serve as forward-looking indicators of banks' lending practices.
} 
of resilience parameters (probabilities of default [PDs], losses given default [LGDs]) for household and bank mortgage portfolios. A policy exercise is implemented to closely approximate the fully phased-in tightening of the borrower-based measures in Slovakia in 2018. A comparison with a counterfactual no-policy scenario quantifies the potential (exante) impact of macroprudential measures on resilience parameters under an adverse macroeconomic scenario.

The paper provides detailed quantitative evidence on the impact of borrower-based macroprudential policies. Our results suggest that:

- $\quad$ Borrower-based measures can noticeably improve household and bank resilience to macroeconomic shocks, in particular when multiple measures are applied;

- $\quad$ Borrower-based measures tend to complement each other, as the impact of individual instruments is largely transmitted via different channels (PD versus LGD); and

- $\quad$ The resilience benefits of borrower-based measures are more sizeable if the measures effectively limit the accumulation of risks before an economic downturn occurs, suggesting that an early implementation of borrower-based measures is warranted.

The model framework and results contributed to informing the most recent macroprudential policy decision in Slovakia related to borrower-based measures, that is, to tighten the debt service-to-income ratio on new retail lending from 80 percent to 60 percent. ${ }^{4}$

Our paper is a methodologically enhanced follow-up to the initial cross-country framework of Gross and Población (2017). This framework can inform the calibration and assessment of macroprudential policies for individual countries and can easily be adapted to reflect more country specificities, as illustrated in the present application to Slovakia. The framework can also serve as a more general scenario-conditional forecasting tool for household risk parameters.

\section{LiterATURE}

The paper relates to the literature in several ways. First, it emphasizes the importance of microdata and models built upon them (1) for informing the timing and calibration of borrower-based macroprudential policy instruments such as loan-to-value (LTV), debt service-to-income (DSTI), and debt-to-income (DTI) ratio caps; and (2) for reviewing the distributional implications of such measures. Annex 1 presents an overview of the existing models in the literature and how the one we present further completes the methodological components that are instrumental for obtaining estimates of PDs and LGDs, in a multi-period simulation framework with endogenous loan granting, and including a link to bank balance sheets.

The macroeconomic importance of household debt is well understood. The role of household debt dynamics - including in the US in the run-up to the global financial crisis of 2007-09-is discussed in Mian and Sufi $(2009,2014)$ and Jòrda et al. $(2013,2016)$. The

\footnotetext{
${ }^{4}$ See the decision of the National Bank of Slovakia of December 2019 (https://www.nbs.sk/en/press/all-pressreleases/press-releases-common/press-release/ statement-from-the-nbs-bank-board-s-24th-meeting-of-2019) and the background analysis in the November 2019 Financial Stability Report (Box 1, https://www.nbs.sk/ img/Documents/ZAKLNBS/PUBLIK/SFS/FSR_112019.pdf), as well as the special feature of the May 2019 FSR (https://www.nbs.sk/_img/Documents/ZAKLNBS/PUBLIK/SFS/FSR_052019.pdf).
} 
turning point analysis of Claessens et al. (2010) confirms that major recessions are typically preceded by credit and housing booms. Similarly, based on cross-country panel data, Schularick and Taylor (2012) conclude that booms in credit and housing are strong predictors of subsequent recessions. The macroeconomic importance of household debt motivates the detailed and integrated micro-macro modeling approach of this paper, to better understand the distributional aspects of mortgage debt in the household population and to inform targeted macroprudential policies.

Microdata for households have been used to assess household debt dynamics and to conduct scenario-based assessments of household vulnerabilities since the early $2000 \mathrm{~s}$ (Annex 1). The earliest contributions are found for Nordic European countries: Finland, Norway, and Sweden (Johansson and Persson 2006, Vatne 2006, Herrala and Kauko 2007). They are followed by a range of analyses for various European countries (for example, Austria, Czech Republic, Hungary, Poland, and others), and also for non-EU countries such as Korea (Karasulu 2008), Chile (Fuenzalida and Ruiz-Tagle 2011), and Canada (Djoudad 2012).

The early literature is largely descriptive, focusing on different vulnerability metrics (conditional on household characteristics) and conducting scenario-conditional sensitivity analyses. Vulnerability metrics usually include financial margins (most often defined as income minus expenses), debt service-to-income ratios, debt-to-asset ratios, and others. Scenario analyses are usually conducted to assess how the vulnerability metrics behave as a function of changing interest rates, unemployment rates, income, and house prices. None of them considers explicit multi-period scenario simulations yet, and virtually none of them operates with explicit PDs and LGDs (as defined by bank stress testers). ${ }^{5}$ As expected, many of them find that employment and hence income dynamics matter most for households' ability to service their debt. ${ }^{6}$

Multi-period stochastic simulation frameworks have been advanced since 2016 (Annex 1, item 20). Such frameworks include Peterson and Roberts (2016) for Canada, and Gross and Población (henceforth GP 2017; see also European Central Bank [ECB] 2016/2017) for European countries developed at the ECB. These frameworks allow for an explicit simulation of the households' P\&L flows and hence their balance sheet stock evolution. GP (2017) is the starting point for the framework presented here; adapted to the Slovak specific context and also extended to consider endogenous loan granting. ${ }^{7}$

\footnotetext{
${ }^{5}$ Many household survey data-based papers do work with the notion of PDs and LGDs, yet with their definitions differing from the PDs and LGDs used by bank stress testers. PDs used in the literature often denote the probability of a household's financial margin (usually defined as income streams minus expense streams) being positive or negative, and LGDs denote the uncollateralized portion of vulnerable households relative to total debt.

${ }^{6}$ A survey paper focusing on the survey data literature can be found in Leika and Marchettini (2017).

${ }^{7}$ Gornicka and Valderrama (2019, forthcoming) present a structural household credit risk model for stress testing and to calibrate borrower-based macroprudential tools, which is similar to our model framework. It has been applied in FSAPs for Switzerland and Austria (IMF 2019). The framework does not use microdata as input but does allow for the derivation of literal PDs and LGDs in the form needed to link them up to a bank stress test. Olafsson and Vignisdottir (2012) is an application to Iceland, which analyzes households' financial position during and after the GFC, involving scenario simulations to assess the effect of policy and legal interventions.
} 
The use of micro simulation frameworks for assessing borrower-based macroprudential policies to date has been limited. Exceptions are Cussen et al. (2015) and GP (2017), which employ microdata for computing borrower-based policy-induced loan demand shocks, to then assess the macroeconomic impact, using a Bayesian vector autoregression (BVAR) in Cussen et al. (2015) and a global vector autoregression (GVAR) in GP (2017). The main difference is that Cussen et al. (2015) do not conduct an explicit simulation of the individual households' P\&L and balance sheets, which is central to the GP (2017) framework. ${ }^{8}$

\begin{abstract}
Stochastic simulation methods are often employed when analyzing the impact of changes in employment conditions (Annex 1). The way such stochastic simulations are implemented - usually based on logistic employment status models - differs across applications. They range from drawing procedures that assume that household members have an equal probability of becoming unemployed by shifting the intercept term in the logistic regression (for example, Johansson and Persson 2006, Holló and Papp 2007, Albacete and Lindner 2010), to allowing the control over transition flows by shifting the intercept for employed and unemployed households separately (Galuščák et al. 2016), to controlling also for the duration of unemployment via the addition of persistence terms in the logistic model's residual coupled with an intercept shift (GP 2017).
\end{abstract}

The IMF Financial Sector Assessment Programs (FSAPs) frequently employ household microdata-based risk factor sensitivity analyses. These include applications to the UK, Spain, Switzerland, Italy, Norway, Finland, Luxembourg, and New Zealand (IMF 2011, IMF 2013, IMF 2015, IMF 2017a/17b). Most of them consider instantaneous impact analyses regarding interest rates, income, and house prices. When they employ multivariate scenarios, they tend to be aligned with the scenarios for the FSAPs' solvency stress test analyses for banks. These analytical methods in FSAPs are similar to those presented in the early literature and hence do not allow for computing PDs and LGDs, in turn disregarding the feedback from household resilience into banks' $\mathrm{P} \& \mathrm{~L}$, balance sheet, and thus bank capital dynamics. Model developments as in Peterson and Roberts (2016) and GP (2017) explicitly establish this link.

Our paper also relates to the empirical assessment of the impact of macroprudential policies on macroeconomic variables. The literature finds that aggregate house price dynamics and LTV distributions appear to be related; countries/regions in which the household population has higher LTVs are more sensitive to economic shocks; see Lamont and Stein (1999) for such findings at the city level and Almeida et al. (2006) at the country level. Crowe et al. (2011) find a positive relation between LTV at origination and subsequent price appreciation using state-level data for the US. Lim et al. (2013) use data from 49 countries to assess the effectiveness of macroprudential instruments such as LTV caps. Their results suggest that many of the instruments are effective in reducing procyclicality, while the

\footnotetext{
${ }^{8}$ DSGE models have also investigated the complementarity between monetary and macroprudential policies, supporting the added stabilization benefits of the latter. Such applications include, for example, Kannan et al. (2012), Angeloni and Faia (2013), Bailliu et al. (2015), and Collard et al. (2017), many of them starting from the framework with debt and collateral constraints related to real estate as developed by Kiyotaki and Moore (1997) and Iacoviello (2005). Mendicino and Punzi's (2014)'s DSGE model suggests that it is Pareto-improving for an LTV cap policy to counter-cyclically respond to house prices, for consumers to be better able to smooth consumption. Gelain et al. (2013)'s DSGE model shows that debt-to-income ratio-based policy measures can be more effective than LTV caps. Contemporary DSGE models like the ones cited here do not involve micro and distributional elements, which are key when assessing borrower-based policies.
} 
effectiveness is sensitive to the type of shock that the financial sector faces. Hong Kong has been subject to the intense empirical research in relation to its LTV cap policy that it has conducted since 2009. Related analyses include Gerlach and Peng (2005), Ahuja and Nabar (2011), Wong et al. (2011), Funke and Patz (2012), and Wong et al. (2014). The evidence suggests that LTV cap tightening policies in Hong Kong since 2009 were successful in curbing borrower leverage and in strengthening banks' resilience to house price shocks. In an application to Romania, Nier et al. (2019) use a micro (credit register)-based econometric model to estimate the effect of DSTI policies on PDs. The relationship between DSTIs and the probability of default is found to be non-linear, and consumer loan defaults happen at lower DSTI thresholds compared to mortgages.

\section{Data And Model Methodology}

\section{Our methodological framework is built upon microdata from the third wave of the Household Finance and Consumption Survey (HFCS) ${ }^{9}$ with macroeconomic time series} from the NBS database. The HFCS survey collects comprehensive information at both the household $(\mathrm{HH})$ and the household member (HHM) level. The variables of interest for our application include mortgage loans, property values, other consumer debt, and liquid financial assets (at the borrowing $\mathrm{HH}$ level) as well as employment status, income, and sociodemographic characteristics (at the HHM level) (Table A1). The microdata on employment and income are used to determine the loan repayment capacity of households. The microdata on loans are used to generate counterfactual new mortgage lending distributions (with associated LTV, DTI, and DSTI characteristics; see Table A2) and mortgage debt payment obligations. For our sample, the distributions of lending standards (and weighted volumes) from the HFCS data are broadly consistent with those reported by Slovak banks in regulatory templates (Figure 2). While lending standards based on survey data can only approximate the distributions obtained from regulatory data, we consider this approximation to be sufficient (as additionally supported by information from more recently collected loan-level data). ${ }^{10}$

\footnotetext{
${ }^{9}$ https://www.ecb.europa.eu/pub/economic-research/research-networks/html/researcher hfen.en.html.

${ }^{10}$ In Annex 3, we present a concise analysis that reveals that households' own assessment of the current value of their house is surrounded by uncertainty.
} 
Figure 2: Distributions of Lending Standards, 2015-17)

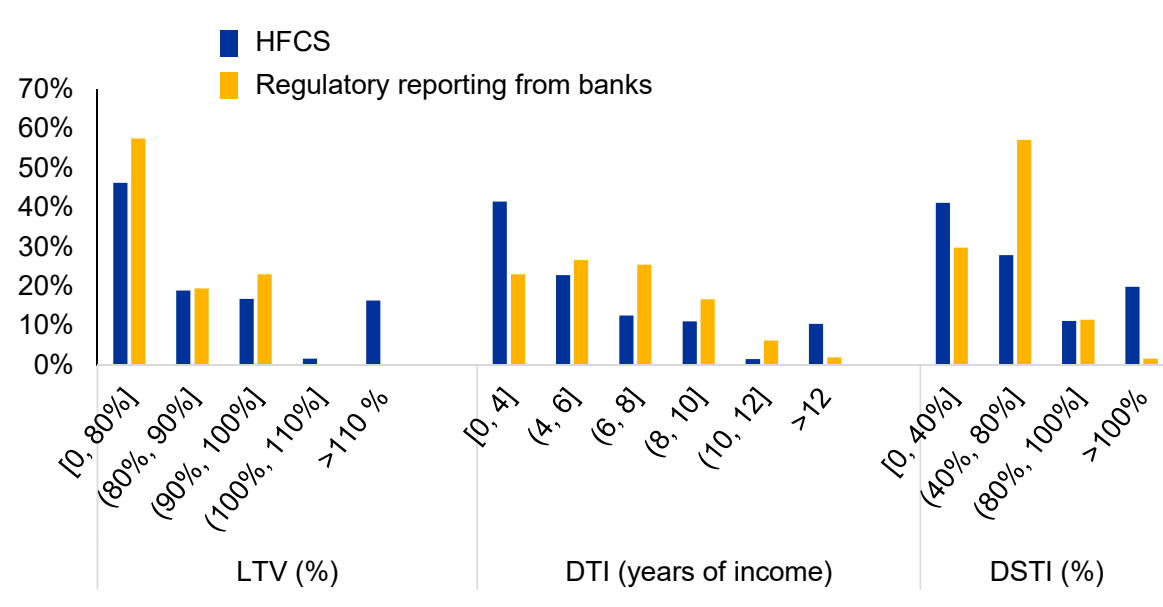

Sources: HFCS, NBS.

Note: Data based on HFCS refer to the period 2015-17. Data from regulatory templates submitted by banks refer to the period before implementation of the particular measure.

The methodology integrates empirical micro modules with a simulation scheme based on a structural macro model into dynamic household balance sheets to determine the impact on household and bank resilience relative to a no-policy scenario over an adverse (stress) three-year period (Figure 3). On the micro side, a logit model is used to determine the probability of staying employed and, when integrated with the aggregate unemployment paths from the macro module, simulate the employment status of household members. A second micro module simulates forward the empirical distributions of new mortgage loans, which are also scaled to match aggregate mortgage lending forecasts coming from a satellite of the macro module. A macro module generates multiple macroeconomic adverse scenarios, with the focal variable being the unemployment rate. A household balance sheet simulator combines the micro and macro inputs to determine the mortgage debt servicing capacity of households and detect defaults over the simulated adverse period. The impact of macroprudential policies is measured in terms of changes to key resilience parameters (PDs, LGDs, and expected losses on bank mortgage portfolios), relative to a nopolicy scenario. 


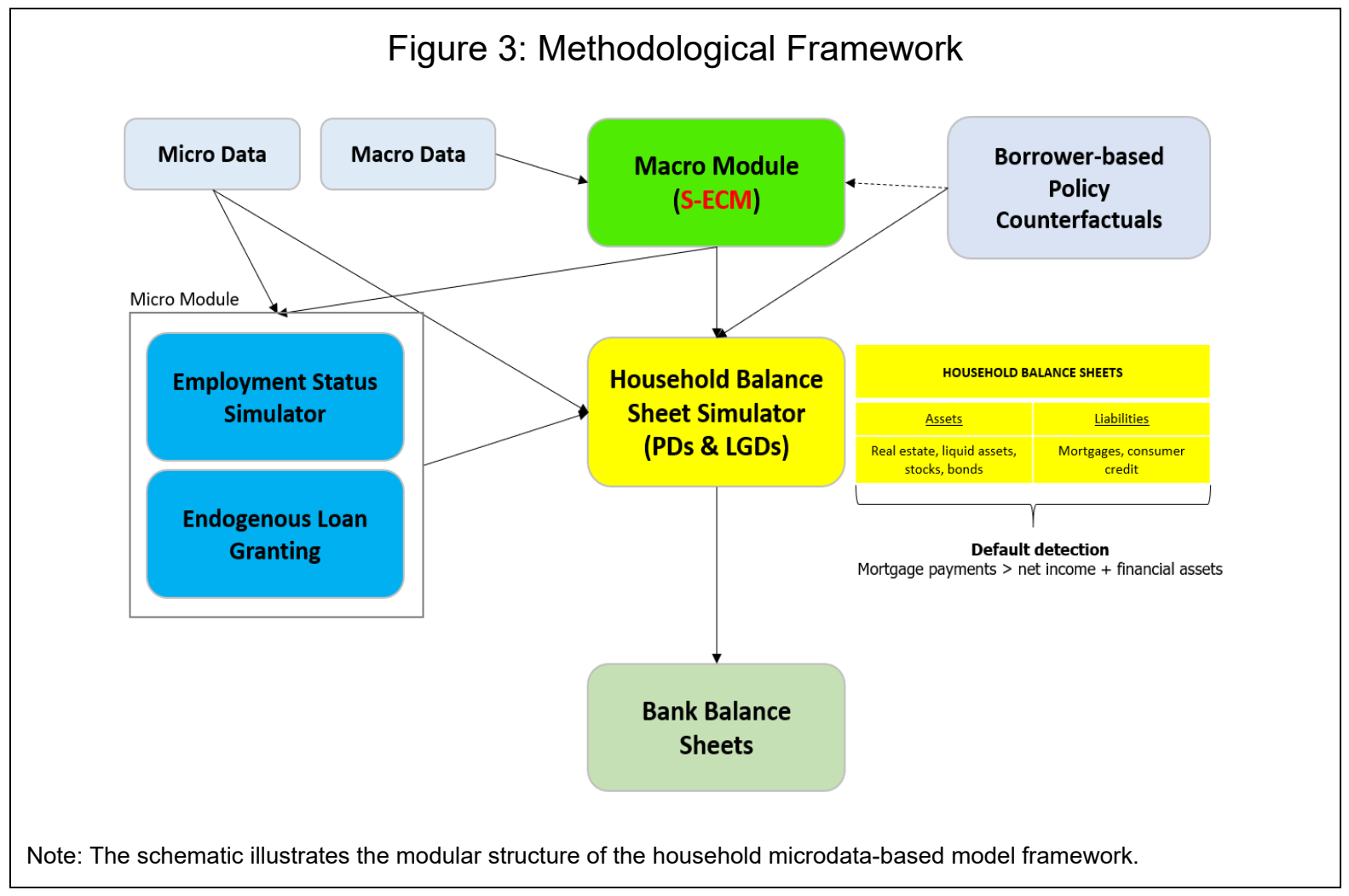

The macro module generates adverse macroeconomic scenarios, which is relevant for assessing the increase in household and bank resilience from implementing combinations of borrower-based measures. The structural macro model employed by the NBS for official medium-term forecasts introduced by Rel'ovský and Široká (2009) was used to generate a three-year central adverse scenario consistent with the one used in the NBS stress test exercise with end-2017 data. ${ }^{11}$ Ten thousand random macro paths were simulated around the central adverse scenario, in a way that reflects the uncertainty surrounding the exogenous foreign variables (foreign demand, foreign prices, oil prices). The aggregate unemployment paths, together with the aggregate mortgage credit growth path from a satellite model, are the key macro inputs into the household balance sheet simulator (Box A1 and Figure 4).

The first part of the micro module uses a logit model to estimate the probability of HHMs' staying employed. The probability of staying employed is a key determinant of the income level that sustains the debt service capacity of the household. The explanatory variables include education, marital status, gender, age, and nationality. Retirees, household members on parental leave, and students are excluded; only employed, self-employed, and unemployed household members are considered in the regression (as in GP 2017). The estimation results suggest that a higher level of education and being married statistically significantly increase the probability of staying employed (Table A4).

\footnotetext{
${ }^{11}$ NBS, "Analysis of the Slovak Financial Sector 2018, Macro stress testing of the Slovak financial sector" (pp. 54-59). The assumptions are designed to achieve a severe yet plausible scenario, guided by developments during the last crisis.
} 


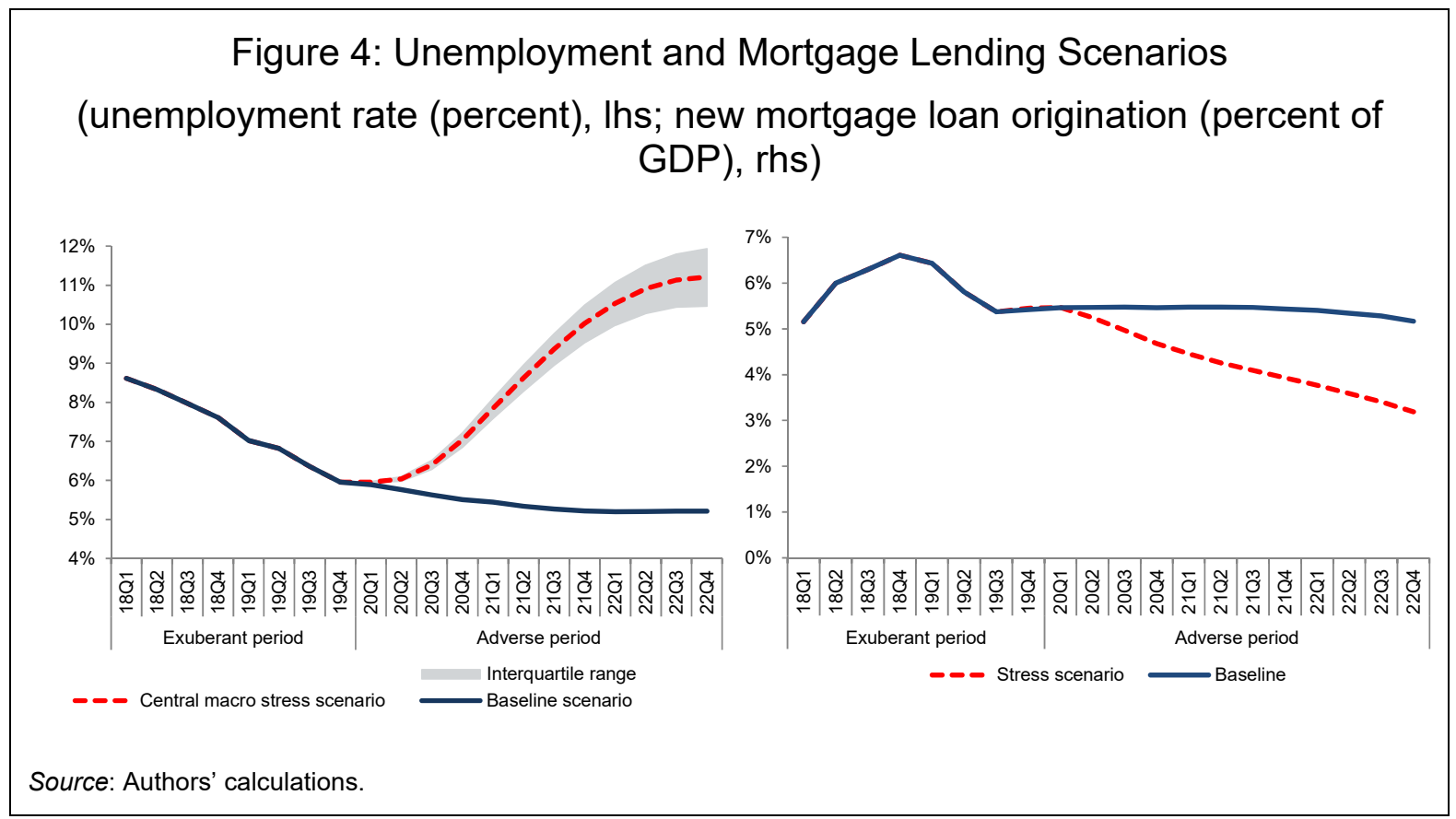

Results from the logit regression are then combined with the changes in the aggregate unemployment from the macro module to determine the probability of HHMs' staying employed over the adverse simulation horizon. These probabilities are mainly relevant for the HHMs who are mortgage debtors. Since in the HFCS data mortgages are only reported at the $\mathrm{HH}$ level and links to particular HHMs are missing, for HHs with more than two HHMs, we use an algorithm that assigns the mortgage loans to the relatively younger income earning members of the household. The loan is assigned to at most two income earning members, for whom the probabilities of staying employed are then simulated. First, HHMs who were unemployed at the time of the survey are assumed to remain unemployed also during the adverse simulation horizon. Second, to ensure consistency with the evolution of the aggregate rate of unemployment in the adverse scenarios, the intercept of the logit regression is adjusted period by period so that the one period change in the implied unemployment rate from the sample of borrowing HHMs matches the change in the aggregate unemployment rate along the adverse simulation horizon. This would in turn determine the probabilities of individual HHMs' staying employed during each period of the simulation horizon (Box A2).

The second part of the micro module generates counterfactual new mortgage lending before and during the adverse period. Distributions of new mortgage lending are simulated for a five-year period (two "exuberant" years followed by the three years of the adverse macroeconomic conditions). Under the no-policy scenario, the distributions of lending standards (LTV, DSTI, and DTI) of new mortgage loans observed in the HFCS data over 2015-17 are carried forward, conditional on matching the changes in aggregate new mortgage lending obtained from a satellite of the macro module (Figures 3 and 4(rhs)). ${ }^{12} \mathrm{New}$

\footnotetext{
${ }^{12}$ The period 2015-17 was chosen because the distributions of lending standards match the even more granular data from the regulatory reporting of banks. The period also includes loans granted in early 2017, as the survey was conducted in 2017. Also, given the phase-in sequence of borrower-based measures in Slovakia, these loans were unlikely to be affected by the latest tightening of measures (2018), which is the basis for our simulated, ex-ante policy exercise and only marginally, if at all, by the first tightening of measure in 2017.
} 
mortgage loans are also simulated for the two years preceding the adverse period to capture the impact of policy measures on riskier loans, which are increasingly granted in the exuberant times just before the adverse developments take place. The volume of individual new loans was obtained by proportionally rescaling the HFCS survey weights (Box A2) to match the one period change in the weighted implied mortgage credit for the sample of borrowing HHMs with the respective change in aggregate new mortgage lending from the satellite of the macro model. The volume of simulated individual new loans accounts for the amortization of outstanding loans (to ensure consistency with the estimate of aggregate outstanding mortgage credit from the satellite model) as well as the decrease in income and collateral expected during the adverse period (assuming unchanged LTV, DSTI, and DTI constraints during the adverse period under no policy).

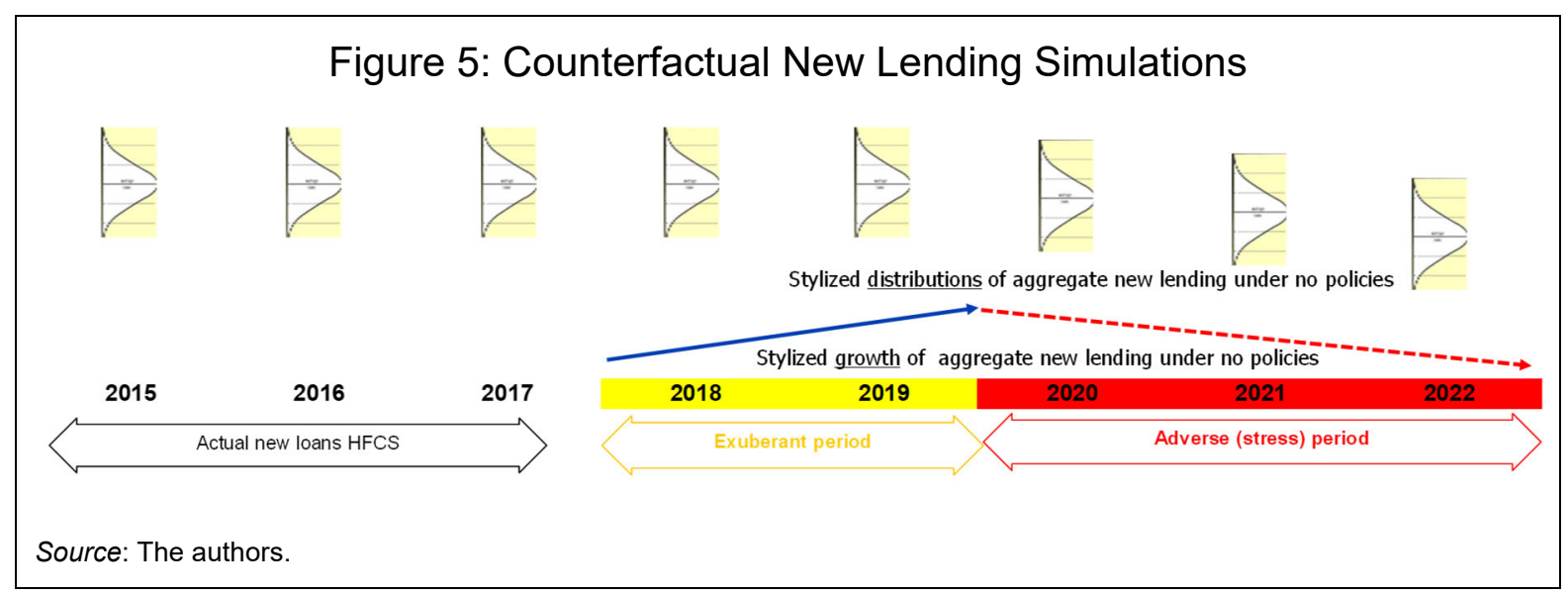

The household balance sheet module combines the micro and macro input into a rule for default detection, allowing the simulation of PDs and LGDs over the three-year adverse period (Box A3). If one or both of the mortgage debtors become unemployed, their income is reduced to an unemployment benefit for the first two quarters, after which the income falls to zero through the end of the adverse period. Since the simulation is conducted conditional on an adverse scenario, the income of borrowers who remain employed is also assumed to decline (although at different paces depending on whether the employment sector is, respectively, most sensitive, less sensitive, or non-sensitive to the business cycle ${ }^{13}$ ) (Tables A5 and A6). A drawdown of household liquid assets and a temporary maturity extension can also be used to augment the income/unemployment benefit. A default event occurs if the combination of income/unemployment benefit, liquid asset depletion, and a temporary maturity extension cannot cover the debt service over a period of 18 months (otherwise the household is assumed to recover ${ }^{14}$ ). In case of a default event, the collateral (real estate value) is recovered minus a haircut equal to the decline in house prices between the moment when the loan was granted and the end of the adverse period, to reflect that real estate prices are

\footnotetext{
13 The cyclicality of a sector depends on the relationship between default rates in that particular sector and GDP decline. For further details, see NBS, "Annexes to the Analysis of the Slovak Financial Sector" (2018).

14 The latter assumption is consistent with the financial crisis experience in Slovakia, where a reasonable forbearance extension supported the recovery of household capacity to service debt without defaulting. In addition, the computation of debt service assumes that the loan principal and interest payments are serviced from origination until the moment of default.
} 
assumed to gradually decline by up to 30 percent through the adverse period. It is further assumed that banks will incur administrative costs related to the recovery of the claim. ${ }^{15}$

\section{Policy Scenario and Simulation Results}

The key objective of the policy scenario simulation is to quantify the expected increase in the resilience of households and reduction in bank mortgage portfolio losses resulting from implementing a combination of borrower-based macroprudential measures as of

the beginning of 2018. The tightening of borrower-based measures in Slovakia announced in 2018 (fully phased in as of July 2019) is closely approximated under a policy scenario: at the beginning of 2018 (at the start of the "exuberant period"), the LTV is tightened to 80 percent (with a 20 percent exemption up to the maximum allowed LTV of 90 percent), the DSTI is limited to 80 percent, and the DTI to eight times the annual income. ${ }^{16}$ Among the three measures, the LTV is most binding in our data sample (in terms of loans issued above the limit), followed by DTI and DSTI (Figure 6). The total share of mortgage lending constrained by the all the measures is 55 percent $(44$ percent +5 percent +3 percent +3 percent).

We assume that the borrower response to policy tightening approximates market practices. Following the policy tightening, we expect borrowers constrained by one or more of the regulatory limits not to be fully excluded from the market, but instead to reduce their borrowing proportionately to comply jointly with all the limits. The share of loans with LTV above 80 percent within the HFCS sample was about 50 percent. To implement the regulatory exemption of up to 20 percent of new loans being allowed with an LTV above 80 percent under the policy scenario, we assume that 60 percent of loans with LTV above 80 percent are reduced to an LTV of 80 percent. The LTV of the remaining mortgages is not changed unless it exceeds 90 percent, in which case it is reduced to 90 percent.

\footnotetext{
${ }^{15}$ Evidence from Slovakia suggests that most borrowers only sell property after default, deferring until being contacted by the bank (consistent with our assumption). Nevertheless, we performed a robustness check assuming that half of the HHs would sell their real estate property voluntarily and the administrative costs incurred for realizing the collateral would decrease from 10 percent to 5 percent. The benefits of the policies would be even larger (a 5 p.p. further reduction in expected losses), as the losses would be more sensitive to LTV constraint, which is significantly tightened in the policy package.

${ }^{16}$ The denominator of the regulatory DSTI limit also excludes a subsistence amount from the after-taxes income. For more information on the regulatory definitions of limits to lending standards in Slovakia, see the explanatory notes of the National Bank of Slovakia (https://www.nbs.sk/ img/Documents/_Dohlad/Makropolitika/UnB-opatrenie prehlad-EN.pdf).
} 
Figure 6: Share of Mortgage Lending above the Policy Caps

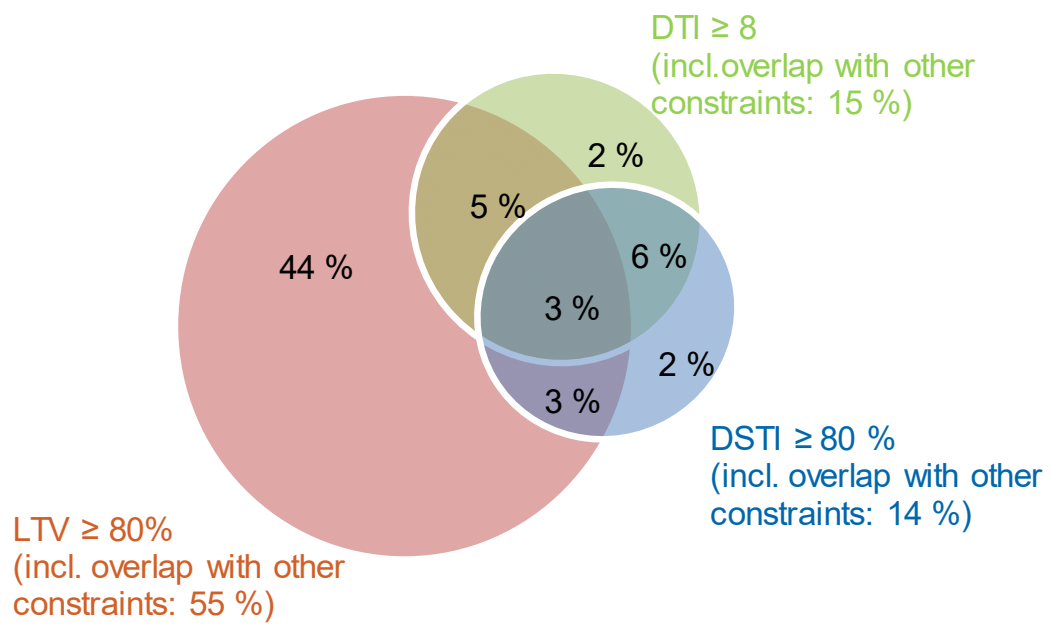

Sources: HFCS and authors' calculations.

Note: The diagram shows the share of new mortgages granted during 2015-17 exceeding regulatory limits or their combinations.

Implementing a combination of borrower-based measures in a sufficiently preemptive manner contributes significantly to the increase in borrower and bank resilience in an adverse scenario (Table 1). ${ }^{17}$ With the combination of borrower-based measures impacting the flow of new mortgage lending, the expected portfolio losses on new mortgage loans granted under the policy scenario decline by almost 40 percent by the end of the adverse horizon, resulting in a reduction of 10 basis points in terms of the mortgage portfolio loss rate. The results also confirm that the main losses stem from new loans granted during the exuberant period, before the simulated economic downturn. Losses from loans granted during 2018-19 represent 67 percent of total cumulative losses over the three-year adverse horizon. An additional 24 percent of losses stem from loans granted in 2020, the first year of the adverse period. Losses from loans originated at a later stage during the adverse scenario are limited. This result reinforces the preventive role of borrower-based measures when activated sufficiently in advance of adverse periods.

\footnotetext{
${ }^{17}$ For details on the formulas for computing the key resilience parameters, see Annex 2, Box A3.
} 


\section{Table 1: Cumulative Impact of Borrower Measures on Resilience and New Lending over the Three-Year Adverse Scenario}

\begin{tabular}{cccc}
\hline Median scenario & Without measures & With measures & Difference \\
\hline Exp. loss $(€$ mil) & 62 & 38 & $-39 \%$ \\
Loss rate & $0.30 \%$ & $0.20 \%$ & $-0.1 \mathrm{pp}$ \\
LGD & $19 \%$ & $13 \%$ & $-6 \mathrm{pp}$ \\
PD & $1.68 \%$ & $1.61 \%$ & $-0.07 \mathrm{pp}$ \\
NPL ratio & $1.56 \%$ & $1.52 \%$ & $-0.04 \mathrm{pp}$ \\
New loans $(€$ bln. $)$ & 20.70 & 18.70 & $-10 \%$ \\
\hline
\end{tabular}

Source: Authors' calculations.

Note: The values show the median scenario cumulative results over the whole stress period (2020-22) for new loans provided during 2018-22. NPL ratio as of end of adverse horizon.

In our simulations, the joint measures exert their impact primarily through changes in LGDs rather than PDs (Figure 7). ${ }^{18}$ The higher impact through the LGD channel stems from the fact that a larger proportion of borrowers in the sample are constrained by the LTV limit (in addition, the tightening of the LTV limit was the most significant relative to the other borrower-based instruments). In terms of relative effect, the results suggest that the LTV cap exerts its impact primarily via the LGD channel, while the DSTI works via the PD channel (as expected). The main contribution to the reduction of the overall expected loss is in the segment of loans previously granted with LTV above 90 percent, where the expected loss halves. Loans with LTV below 80 percent experience only a small decline in expected losses. At the same time, the results indicate a higher contribution by the DTI to slowing down the growth of household indebtedness (via its impact on new mortgage lending volumes) compared to its impact on portfolio riskiness, in line with the original policy objective of the DTI measure.

The impact of macroprudential measures on new mortgage lending is moderate. ${ }^{19}$ However, the 10 percent decline in new mortgage lending would still translate into a slowdown in outstanding mortgage credit growth of 1 to 2 p.p. per year (Figure 8). In addition, the impact on new lending is frontloaded, as it already starts to occur before the adverse period. In that period, a contraction of new lending as a result of early policy

${ }^{18}$ Other studies (for example, Allen et al. (2017) and Alam et al. (2019)) also find a stronger relative impact of LTV limits. However, it is important to recall that the mortgage loan recourse system (full, in the case of Slovakia), as well as the characteristics of the lending standard distributions and binding-ness of policy caps, all play a role in determining the relative impact of LTV versus income-based policy limits. In addition, the paper focuses on evaluating the calibration of enacted policies, and alternative sequencings of policies are beyond its scope.

${ }^{19}$ The paper focuses on the policy benefits under an adverse yet plausible macroeconomic scenario in a small, open economy. As such, we expect the magnitude of the macro feedback effect from policy constraints to be limited. A more detailed cost-benefit analysis considering cyclical dampening effects, however warranted, is left for future analysis. 
interventions can be considered a benefit rather than a cost, given that the strong credit growth in this period was excessive. Conversely, the policy measures also affect the volume of new lending during the adverse period, albeit with a diminishing impact in absolute terms compared to the exuberant period. More generally, an adverse period could trigger a loosening of the measures that could contribute to further reducing the impact on new mortgage lending.

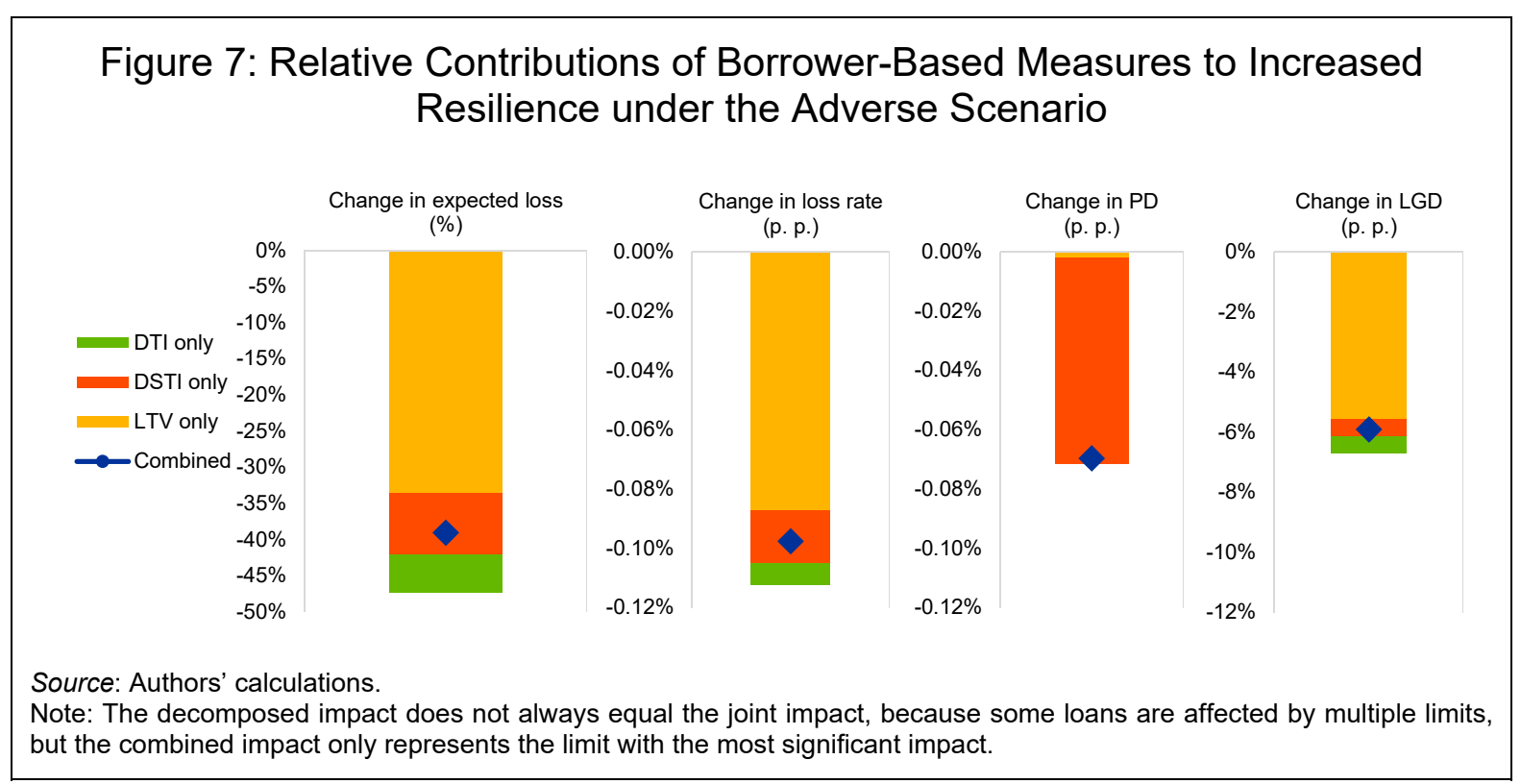

Figure 8: Impact of Borrower-Based Measures on New Lending During the Exuberant and Adverse Periods

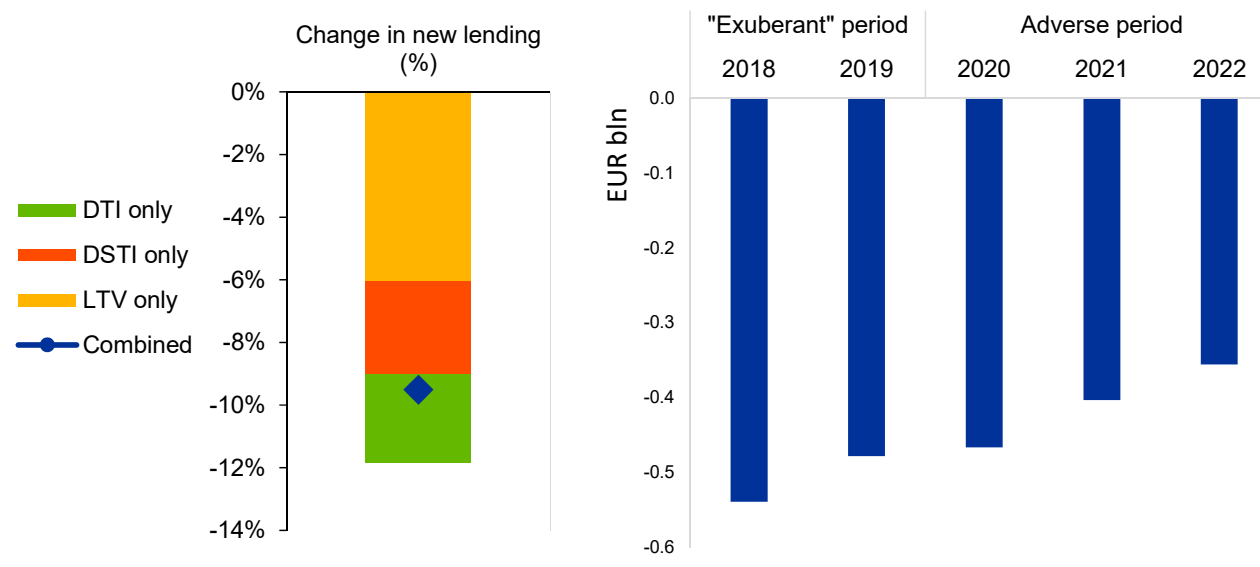

Source: Authors' calculations.

The differentiated transmission over the adverse period suggests that the relative benefits of the individual policy instruments change over time (Figure 9). In particular, the policy benefits of a reduction in PDs are more significant toward the end of the simulation horizon, while the reduction in LGDs is more pronounced at the beginning. The reason for the former is that the gradual increase in unemployment and decrease in income 
(determinants of PDs) are progressively worsening through the adverse period (the unemployment benefit has some deferring effect as well). The latter is due to the fact that loans granted during but closer to the end of the adverse period face a smaller decline in house prices (that is, the determinants of LGD are worsening progressively less toward the end of the stress horizon).

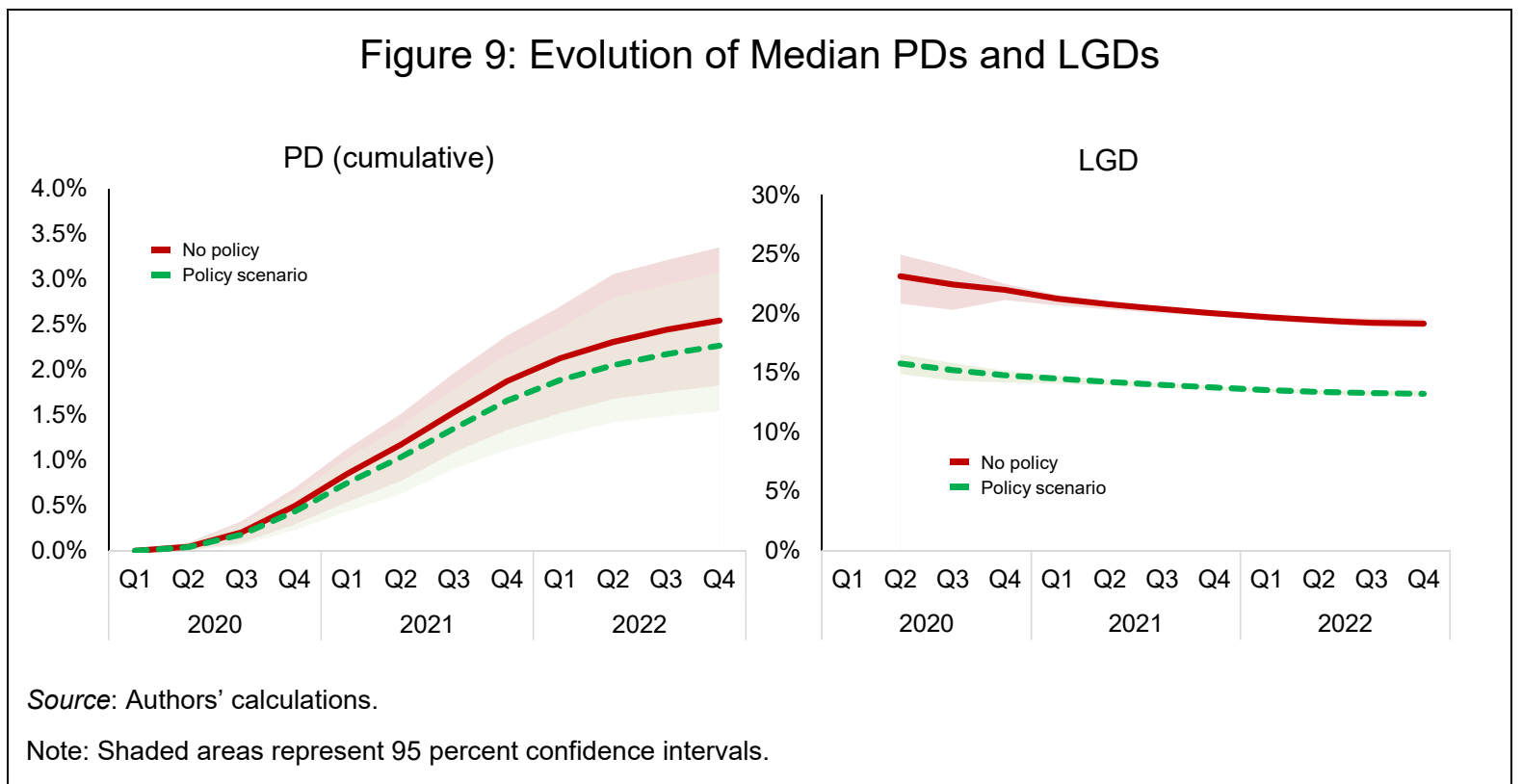

A sensitivity analysis confirms that the main results are robust to changes in key borrower behavior assumptions. We considered two additional alternatives to further support debt service (help from other family members and borrowers' ability to temporarily shrink their living costs below the subsistence minimum), and also the effect of excluding the support from depleting financial assets (given limited financial assets beyond residential property) and forbearance. None of these materially changes the impact of the effectiveness of the policies in our simulation (Table 2). Nevertheless, these factors can have implications for credit risk during the adverse scenario (with the important role of support from other HHMs confirmed by the experience from the last crisis in Slovakia). ${ }^{20}$

\footnotetext{
${ }^{20}$ The sensitivity analysis addresses alternative borrower responses, given the explicit focus of the paper on the dynamic behavior of households. Nevertheless, the symmetric uncertainty around the central adverse macroeconomic scenario due to foreign demand shocks (Figure 4), yields a 95 percent confidence interval of $+/-1$ b.p. around the median 7 b.p. decrease in aggregate PD, and 1.6 p.p. around the median 6 p.p. decrease in aggregate LGD.
} 
Table 2: Sensitivity Analysis

\begin{tabular}{|c|c|c|}
\hline Assumption & $\begin{array}{l}\text { Included in } \\
\text { the original } \\
\text { model? }\end{array}$ & $\begin{array}{c}\text { Change } \\
\text { in loss rate }\end{array}$ \\
\hline Ability to shrink living costs to $1 / 2$ of subsistence minimum & No & $-0.09 \mathrm{pp}$ \\
\hline Inability to reduce debt service by maturity extension & Yes & $0.04 \mathrm{pp}$ \\
\hline
\end{tabular}

Source: Authors' calculations.

Data limitations prevent a more elaborate sensitivity analysis regarding the timing of policy introduction/recalibration or duration of phase-in. Nevertheless, it is reasonable to conclude that an earlier introduction would have increased the policy benefits, as the riskiness of a larger share of new lending would have been reduced. The choice of phase-in periods, if any, depends on weighing the costs of front-loading after the policy announcement, with the benefit of allowing a smoother adjustment to the new policy limits.

\section{The INTERACTION OF BORROWER-BASEd AND CAPITAL-BASEd MEASURES}

To illustrate the potential interaction between borrower- and capital-based measures, a simple computation could translate the impact of borrower-based measures into lower potential capital requirements. For the computation, we use the macro stress testing framework of the NBS and the results of the stress testing as of end-2018. The stress testing assumes a drop in domestic GDP and an increase in the unemployment ratio, which is mirroring the central adverse scenario used in this paper. Within the stress testing framework, a satellite model is used to estimate the development of the volume of housing loans under the stress scenarios (the same estimated development that was used also in the policy simulation exercise in this paper) and another satellite model is used to estimate the development of the volume of nonperforming loans (Annex 2). We further assumed that nonperforming loans do not generate any interest income.

Borrower-based measures impact the balance sheet of banks in multiple ways. The impact can be positive, via lowering expected credit risk-related losses from housing retail loans and lower risk weights (given lower risk parameters), as well as negative, via the foregone interest revenues due to lending contraction. In our illustrative computation, the decrease in expected losses due to the implementation of borrower-based measures is broadly offset by foregone interest revenues. In addition, the impact of borrower-based policy measures through banks' risk-weighted assets (RWA) (and related capital requirements, to shield against unexpected losses) appears to be quantitatively important.

In our illustrative computation, the policies contribute to improving capital adequacy ratios by 0.2 percent of $R W A$ through decreasing credit losses over the three-year adverse horizon (Figure 10). As the adverse scenario and the volume of housing loans in 
the end-2018 macro stress testing exercise coincides with the central stress scenario used in this policy exercise, the estimated cumulative three-year credit losses from housing loans ( 0.5 percent of RWA) under the adverse scenario are taken from the macro stress testing results. A hypothetical scenario is considered in which the borrower-based measures are assumed to have been implemented already for a long time (that is, their impact is assumed to be already cumulated in the stock of loans). Multiplying the cumulative loss under the no-policy scenario ( 0.5 percent of RWA) with the loss reduction under policies ( 39 percent; see Table 1) translates into an equivalent increase in capital adequacy. This estimation covers the effect of policy measures on housing loans only; their effect on consumer loans was not estimated and hence is not covered in this exercise.

\section{Chart 10: Contribution of Borrower-Based Measures to Bank Resilience}

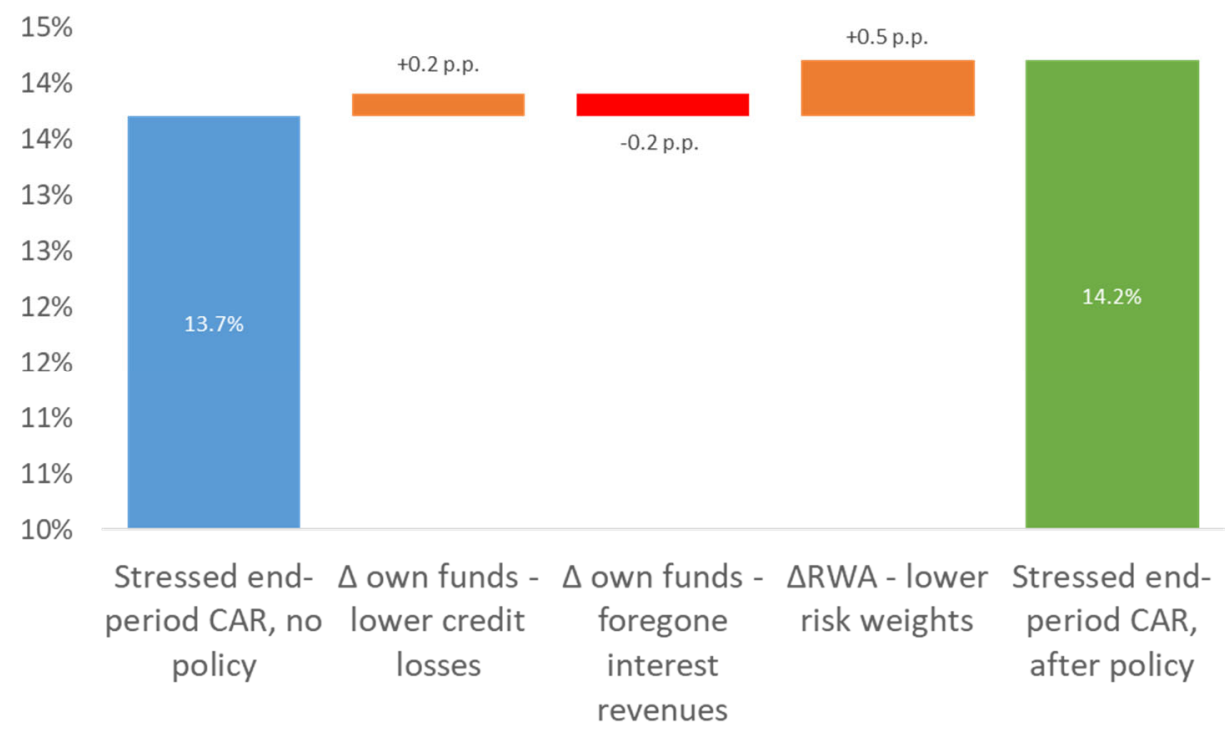

Source: Authors' calculations.

Note: The scenario assumes the full pass-through of borrower-based measures into the stock of mortgage lending.

In addition, policies contribute to improving capital adequacy ratios by 0.5 percent of RWA due to lower risk weights. In terms of risk parameters, the main effect of borrowerbased measures is through the fall in LGDs by about one quarter. Their effect through PDs is rather limited. As a result, risk weights on housing loans for banks' IRB portfolios would decrease by one quarter since they are proportional to LGDs. As a result, the total capital adequacy ratio would be 0.5 p.p. higher compared to no-policy scenario.

Finally, the negative effect in terms of foregone interest revenues is 0.2 percent of $R W A$ cumulative over the adverse scenario period. This effect is calculated as the absolute change in lending volumes as a result of policy implementation multiplied by the average interest rate in the housing loan portfolio. The calculation also includes the moderation in lending already starting in the exuberant period. 


\section{Conclusions ANd Policy Implications}

Integrated micro-/macro-data and methodologies are instrumental for assessing the effectiveness of macroprudential policies to address risks stemming from the household sector. First, microdata contain information about the distribution and evolution of risks in the population of borrowers and implicitly bank mortgage/household portfolios. As borrower-based macroprudential measures aim to enhance borrower and bank resilience (in addition to possibly taming exuberant housing market dynamics), a detailed understanding of the impact of "high-risk" lending is extremely important. Second, microdata can help to inform the determinants of employment and income of borrowers, which in turn are key factors for households' probability of default. Third, as borrower-based measures are increasingly judged to work better in combinations, microdata are crucial to understand how combinations of borrower-based measures are related to the distributions of lending standards, individually and jointly. Fourth, an integrated macro module anchors the individual household balance sheets into the broader economy and provides forward paths for macroeconomic aggregates.

In addition, the use of household microdata is important for the analysis of distributional effects of macroprudential policies. While beyond the scope of this paper, a detailed analysis of policy impact across the age, income, and employment distribution of borrowers is an important component of policy costs and is left for future research.

Using a country-specific application of an integrated micro-macro model framework, our analysis finds that combinations of borrower-based measures enhance household and bank resilience. Our results suggest that combinations of borrower-based measures improve resilience to macroeconomic shocks. In particular, measures such as limits to LTV, DSTI, and DTI tend to complement each other, as the impact of various instruments is transmitted via different channels. Importantly, the policy benefits in terms of resilience are all the more significant if the measures effectively limit the accumulation of high-risk lending before an economic downturn materializes. Given that these policies impact the flow of new lending and therefore take time to strengthen the resilience to shocks, our results suggest that an early, preemptive implementation of borrower-based measures is clearly warranted. Finally, our results suggest that borrower-based policies may have the potential to influence endogenous business cycle dynamics, that is, to not only render the economy and banking system more resilient to shocks, but to also decrease the likelihood of the buildup of imbalances and the materialization of subsequent recessionary scenarios. 


\section{REFERENCES}

Ahuja, A., and M. Nabar, 2011. "Safeguarding Banks and Containing Property Booms: Cross-Country Evidence on Macroprudential Policies and Lessons from Hong Kong SAR," IMF Working Paper No. 11/284.

Alam, Z., A. Alter, J. Eiseman, and others, 2019. "Digging Deeper-Evidence on the Effects of Macroprudential Policies from a New Database,” IMF Working Paper No. 19/66.

Albacete, N., and P. Fessler, 2010. "Stress Testing Austrian Households," OeNB Financial Stability Report 19, 72-91.

—, and P. Lindner, 2013. "Household Vulnerability in Austria-A Microeconomic Analysis Based on the Household Finance and Consumption Survey," OeNB Financial Stability Report 25, 57-73.

Allen, J., T. Grieder, B. Peterson, and others, 2017. "The Impact of Macroprudential Housing Finance Tools in Canada,” Journal of Financial Intermediation, 100761.

Almeida, H., M. Campello, and C. Liu, 2006. "The Financial Accelerator: Evidence from International Housing Markets," Review of Finance, Vol. 10 (3), 1-32.

Angeloni, I., and E. Faia, 2013. "Capital Regulation and Monetary Policy with Fragile Banks," Journal of Monetary Economics, Vol. 60 (3), 311-24.

Arins, M., N. Sinenko, and L. Laube, 2014. "Survey-Based Assessment of Household Borrowers' Financial Vulnerability, Latvijas Banka Discussion Paper.

Bailliu, J., C. Meh, and Y. Zhang, 2015. "Macroprudential Rules and Monetary Policy When Financial Frictions Matter," Economic Modelling, Vol. 50, pp. 148-161.

Claessens, S., Kose, M.A. and M.E. Terrones, 2010. Financial cycles: What? How? When? In: NBER International Seminar on Macroeconomics 2010, NBER Chapters, pp. 303-343.

Collard, F., Dellas, H., Diba, B.T. and O. Loisel, 2017. Optimal monetary and prudential policies. American Economic Journal, Vol. 9, pp. 40-78.

Costa, S. and L. Farinha, 2012. Households' indebtedness: A microeconomic analysis based on the results of the households' financial and consumption survey Financial Stability Report May 2012, Banco de Portugal.

Crowe, C., G. Dell'Ariccia, D. Igan, and others, 2011. "Policies for Macrofinancial Stability: Options to Deal with Real Estate Booms," IMF Staff Discussion Note 11/02.

Cussen, M., M. O'Brien, and L. Onorante, 2015. "Assessing the Impact of Macroprudential Measures," Central Bank of Ireland Economic Letter, Series 2015, Vol. 3. 
Djoudad, R., 2012. "A Framework to Assess Vulnerabilities Arising from Household Indebtedness Using Microdata,” Bank of Canada Discussion Paper No. 12-3.

European Central Bank, 2016. "A Model of the Euro Area Household Sector for Stress Testing and Assessing the Efficacy of Lending Standard-Related Macroprudential Policy Measures," Macroprudential Bulletin, Issue 1/2016, Section 2.2

Fuenzalida, M., and J. Ruiz-Tagle, 2011. "Household Financial Vulnerability," in: Rodrigo Alfaro (ed.), Financial Stability, Monetary Policy, and Central Banking, Vol. 15, Ch. 10, 299-326, Central Bank of Chile.

Galuščák, K., P. Hlaváč, and P. Jakubík, 2016. "Household Resilience to Adverse Macroeconomic Shocks: Evidence from Czech Microdata," International Review of Applied Economics, Vol. 30, 377-402.

Gelain, P., K.J. Lansing, and C. Mendicino, 2013. "House Prices, Credit Growth and Excess Volatility: Implications for Monetary and Macroprudential Policy," International Journal of Central Banking, Vol. 9, 219-76.

Gornicka, L., and L. Valderrama, 2019. "Stress Testing and Calibration of Macroprudential Policy Tools," forthcoming.

Gross, M., and J. Población, 2017. “Assessing the Efficacy of Borrower-Based Macroprudential Policy Using an Integrated Micro-Macro Model for European Households," Economic Modelling, Vol. 61, 510-28.

_ 2017. "STAMP€: Stress Test Analytics for Macroprudential Purposes in the Euro Area," Chapter 15, “The Integrated Dynamic Household Balance Sheet (IDHBS) Model of the Euro Area Household Sector," European Central Bank.

Harrison, O., P. Jurča, P., Š. Rychtárik, and others, 2018 “Credit Growth and Macroprudential Policies in the Slovak Republic,” IMF Country Report 18/242.

Herrala, R, and K. Kauko, 2007. "Household Loan Loss Risk in Finland-Estimations and Simulations with Micro Data," Bank of Finland Research Discussion Papers, No. 5/2007.

Holló, D., and M. Papp, 2007. “Assessing Household Credit Risk: Evidence from a Household Survey," Magyar Nemzeti Bank (Central Bank of Hungary) Occasional Papers No. 70.

Igan, D., and H. Kang, 2011. "Do Loan-to-Value and Debt-to-Income Limits Work? Evidence from Korea,” IMF Working Paper No. 11/297.

International Monetary Fund, 2011. "United Kingdom: Vulnerabilities of Household and Corporate Balance Sheets and Risks for the Financial Sector," IMF Country Report No. 11/229, Technical Note. 
- 2012. "Spain: Vulnerabilities of Private Sector Balance Sheets and Risks to the Financial Sector," IMF Country Report No. 12/140, Technical Note.

_ 2013. "Italy: "The Financial Situation of Italian Households and Non-Financial Corporations and Risks to the Banking System," IMF Country Report Number 13/348, Technical Note.

— 2015 . "Norway: Selected Issues,” IMF Country Report No. 15/250, Technical Note. _ 2017a. "Finland FSAP: Stress Testing the Banking System and Interconnectedness Analysis, IMF Country Report No. 17/6, Technical Note.

—, 2017b. "Luxembourg FSAP: Risk Analysis," IMF Country Report No. 17/261, Technical Note.

— 2019. "Switzerland FSAP: Stress Testing the Banking Sector," IMF Country Report No. 19/189, Technical Note.

Johansson, M., and M. Persson, 2006. "Swedish Households' Indebtedness and Ability to Pay-A Household Level Study," Sveriges Riksbank Economic Review, Vol. 3, 24-41.

Jòrda, O., M. Schularick, and A.M. Taylor, 2016. “The Great Mortgaging: Housing Finance, Crises and Business Cycles," Economic Policy, Vol. 31(85), 107-52.

- 2017. "Macrofinancial History and the New Business Cycle Facts," NBER Macroeconomics Annual, Vol. 31(1), 213-63.

Kannan, P., P. Rabanal, and A.M. Scott, 2012. "Monetary and Macroprudential Policy Rules in a Model with House Price Booms," B.E. Journal of Macroeconomics, Vol. 12 (1), 1-44.

Karasulu, M., 2008. "Stress Testing Household Debt in Korea," IMF Working Paper No. $08 / 255$.

Lambertini, L., C. Mendicino, and M.T. Punzi, 2013. "Leaning Against Boom-Bust Cycles in Credit and Housing Prices," Journal of Economic Dynamics and Control, Vol. 37(8), 150022.

Leika, M., and D. Marchettini, 2017. "A Generalized Framework for the Assessment of Household Financial Vulnerability," IMF Working Paper No. 17/228.

Lim, C., F. Columba, A. Costa, and others, 2011. "Macroprudential Policy: What Instruments and How to Use Them? Lessons from Country Experiences," IMF Working Paper No. 11/238.

Lindquist, K.G., M.D. Riiser, H. Solheim, and others, 2014. "Ten Years of Household Micro Data: What Have We Learned?" Norges Bank Staff Memo No. 8. 
Mian, A., and A. Sufi, 2009. "The Consequences of Mortgage Credit Expansion: Evidence from the US Mortgage Default Crisis," The Quarterly Journal of Economics, Vol. 124(4), 1449-96.

_ 2011. "House Prices, Home Equity-Based Borrowing, and the US Household Leverage Crisis," American Economic Review, Vol. 101(5), 2132-56.

Michelangeli, V., and M. Pietrunti, 2014. "A Microsimulation Model to Evaluate Italian Households' Financial Vulnerability," International Journal of Microsimulation, Vol. 7(3), 53-79.

National Bank of Slovakia, 2018. "Analysis of the Slovak Financial Sector."

Nier, E., R. Popa, M. Shamloo, and others, 2019. "Debt Service and Default: Calibrating Macroprudential Policy Using Micro Data,” IMF Working Paper No. 19/182.

Olafsson, T., and K. Vignisdottir, 2012.'Households' Position in the Financial Crisis in Iceland, Central Bank of Iceland," Central Bank of Iceland, Department of Economics Working Paper 59.

Peterson, B, and T. Roberts, 2016. "Household Risk Assessment Model," Bank of Canada Technical Report No. 106.

Rel'ovský, B., and J. Široká, 2009. “A Structural Model of the Slovak Economy,” Biatec, Vol. 17, No. 7/2009, 9-14.

Schularick, M., and A.M. Taylor, 2012. "Credit booms gone bust: Monetary policy, leverage cycles, and financial crises, 1870-2008," American Economic Review, Vol. 102(2), 1029-61.

Vatne, B.H., 2006. "How Large Are the Financial Margins of Norwegian Households? An Analysis of Micro Data for the Period 1987-2004," Norges Bank Economic Bulletin 4/06, 173-80.

Zajaczkowski, S., and D. Zochowski, 2007. "The Distribution and Dispersion of Debt Burden Ratios among Households in Poland and Its Implications for Financial Stability," in: Bank for International Settlements (ed.), Proceedings of the IFC Conference on "Measuring the Financial Position of the Household Sector," Vol. 2, 62-74. 
ANNEX 1: LITERATURE

\begin{tabular}{|c|c|c|c|c|c|c|c|c|c|c|c|c|c|c|c|c|c|c|}
\hline \multirow[b]{2}{*}{$\#$} & \multirow[b]{2}{*}{ Reference } & \multirow[b]{2}{*}{ Country } & \multirow[b]{2}{*}{$\begin{array}{c}\text { FM flow } \\
\text { based }\end{array}$} & \multirow[b]{2}{*}{$\begin{array}{l}\text { FM flow- } \\
\text { stock- } \\
\text { based }\end{array}$} & \multicolumn{11}{|c|}{ Forward-looking / scenario-conditional analysis } & \multirow[b]{2}{*}{\begin{tabular}{|c} 
Link to bank \\
stress test
\end{tabular}} & \multirow[b]{2}{*}{\begin{tabular}{|c|} 
Borrower- \\
based \\
MPRU \\
policy \\
application \\
\end{tabular}} & \multirow[b]{2}{*}{ \# } \\
\hline & & & & & $\begin{array}{c}\text { Interest } \\
\text { rates }\end{array}$ & $\begin{array}{c}\text { Employ- } \\
\text { ment }\end{array}$ & Income & $\begin{array}{l}\text { House } \\
\text { prices }\end{array}$ & $\begin{array}{c}\text { Multivariate } \\
\text { shock } \\
\text { scenarios }\end{array}$ & $\begin{array}{c}\text { One-period/ } \\
\text { instantaneous }\end{array}$ & $\begin{array}{l}\text { Multi- } \\
\text { period }\end{array}$ & $\begin{array}{c}\text { Stoch. } \\
\text { treatment } \\
\text { of empl. } \\
\text { status in }\end{array}$ & $\begin{array}{c}\text { Endogenous } \\
\text { mortgage } \\
\text { origination }\end{array}$ & PDs & LGDs & & & \\
\hline 1 & "Johansson \& Persson (2006) & Sweden & 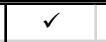 & & 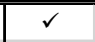 & 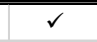 & 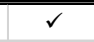 & 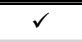 & & 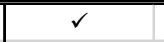 & & $\bar{c}$ & & & & & & 1 \\
\hline 2 & Vatne (2006) & Norway & $\checkmark$ & & $\checkmark$ & & & & & $\checkmark$ & & & & & & & & 2 \\
\hline 3 & Herrala \& Kauko (2007) & Finland & $\checkmark$ & & $\checkmark$ & $\checkmark$ & & $\checkmark$ & & $\checkmark$ & & $\checkmark$ & & & & & & 3 \\
\hline 4 & Hollo \& Papp (2007) & Hungary & $\checkmark$ & & $\checkmark$ & $\checkmark$ & & & $\checkmark$ & $\checkmark$ & & $\checkmark$ & & $\checkmark$ & & $\checkmark$ & & 4 \\
\hline 5 & Zajaczkowski \& Zochowski (2007 & Poland & $\checkmark$ & & $\checkmark$ & & & & & $\checkmark$ & & & & & & & & 5 \\
\hline 6 & Karasulu (2008) & Korea & & $\checkmark$ & $\checkmark$ & & & $\checkmark$ & $\checkmark$ & $\checkmark$ & & & & & & & & 6 \\
\hline 7 & Albacete \& Fessler (2010) & Austria & $\checkmark$ & & $\checkmark$ & $\checkmark$ & & $\checkmark$ & & $\checkmark$ & & $\checkmark$ & & & & & & 7 \\
\hline 8 & Fuenzalida \& Ruiz-Tagle (2011) & Chile & $\checkmark$ & & & $\checkmark$ & & & & $\checkmark$ & & $\checkmark$ & & & & & & 8 \\
\hline 9 & IMF (2011) & UK & $\checkmark$ & & $\checkmark$ & & $\checkmark$ & $\checkmark$ & $\checkmark$ & $\checkmark$ & & & & & & & & 9 \\
\hline 10 & Costa \& Farinha (2012) & Portugal & & & & & & & & $\checkmark$ & & & & & & & & 10 \\
\hline 11 & Djoudad (2012) & Canada & $\checkmark$ & $\checkmark$ & $\checkmark$ & $\checkmark$ & $\checkmark$ & & $\checkmark$ & & & $\checkmark$ & $\checkmark$ & & & & & 11 \\
\hline 12 & IMF (2012) & Spain & $\checkmark$ & & $\checkmark$ & $\checkmark$ & $\checkmark$ & $\checkmark$ & & $\checkmark$ & & $\checkmark$ & & & & & & 12 \\
\hline 13 & Albacete \& Lindner (2013) & Austria & $\checkmark$ & & & & & & & $\checkmark$ & & & & & & & & 13 \\
\hline 14 & IMF (2013) & Italy & & & $\checkmark$ & & $\checkmark$ & $\checkmark$ & $\checkmark$ & $\checkmark$ & & & & & & & & 14 \\
\hline 15 & Arins et al. (2014) & Latvia & & $\checkmark$ & $\checkmark$ & $\checkmark$ & $\checkmark$ & & $\checkmark$ & $\checkmark$ & & $\checkmark$ & & & & & & 15 \\
\hline 16 & Lindquist et al. (2014) & Norway & $\checkmark$ & & $\checkmark$ & & & $\checkmark$ & $\checkmark$ & $\checkmark$ & & & & & & & & 16 \\
\hline 17 & Michelangeli \& Pietrunti (2014) & Italy & $\checkmark$ & & $\checkmark$ & & $\checkmark$ & & & $\checkmark$ & & & $\checkmark$ & & & & & 17 \\
\hline 18 & Cussen et al. (2015) & Ireland & & & & & & & & & $\checkmark$ & & & & & & $\checkmark$ & 18 \\
\hline 19 & IMF (2015) & Norway & & & $\checkmark$ & & $\checkmark$ & $\checkmark$ & $\checkmark$ & $\checkmark$ & & & & & & & & 19 \\
\hline 20 & Galuščák et al. (2016) & Czech Rep. & $\checkmark$ & & $\checkmark$ & $\checkmark$ & $\checkmark$ & & $\checkmark$ & $\checkmark$ & & $\checkmark$ & & & & & & 20 \\
\hline 21 & Peterson and Roberts (2016) & Canada & & $\checkmark$ & $\checkmark$ & $\checkmark$ & $\checkmark$ & $\checkmark$ & $\checkmark$ & & $\checkmark$ & $\checkmark$ & $\checkmark$ & $\checkmark$ & & & & 21 \\
\hline 22 & Gross \& Poblacion (2017) & Euro area countrie & & $\checkmark$ & $\checkmark$ & $\checkmark$ & $\checkmark$ & $\checkmark$ & $\checkmark$ & & $\checkmark$ & $\checkmark$ & & $\checkmark$ & $\checkmark$ & $\checkmark$ & $\checkmark$ & 22 \\
\hline 23 & IMF (2017a) & Finland & & $\checkmark$ & & & $\checkmark$ & & & $\checkmark$ & & & & & & & & 23 \\
\hline 24 & IMF (2017b) & Luxembourg & $\checkmark$ & & & $\checkmark$ & $\checkmark$ & $\checkmark$ & $\checkmark$ & $\checkmark$ & & & & & & & & 24 \\
\hline 25 & Nier et al. (2019) & Romania & & & & & & & & & & & & $\checkmark$ & & & $\checkmark$ & 25 \\
\hline 26 & This paper & Slovakia & & $\checkmark$ & $\checkmark$ & $\checkmark$ & $\checkmark$ & $\checkmark$ & $\checkmark$ & & $\checkmark$ & $\checkmark$ & $\checkmark$ & $\checkmark$ & $\checkmark$ & $\checkmark$ & $\checkmark$ & 26 \\
\hline
\end{tabular}

Note: The table summarizes the literature that employs household survey/microdata to analyze household debt dynamics, their dependence on sociodemographic factors, and macroeconomic drivers such as interest rates, employment conditions, house prices, and so on. "FM" abbreviates financial margin. "Flow-based financial margins" are defined as income minus expense flows (consumption and debt service). FMs with additional "stock" components account for the presence of savings stocks (for example, sight and term deposits) next to the income and expense flow components. See text for details. 
Annex 2: AdDitional Model Details

Table A1. Household and Household Member Level Data from HFCS

\begin{tabular}{|c|c|c|}
\hline Category & Variable ID & Variable name \\
\hline \multirow[t]{4}{*}{ IDs } & sa0010 & Household identification number \\
\hline & ra0010 & Personal ID \\
\hline & im0100 & Imputation sample ID \\
\hline & $\mathrm{ra0010}$ & Personal identification number \\
\hline \multirow[t]{15}{*}{ Income and employment status (HHM level) } & pe0400 & Main employment - NACE \\
\hline & pe0100 & Labour status \\
\hline & pg0110 & gross cash employee income \\
\hline & pg0210 & gross self-employment income (profit/losses of unincorporated enterprises) \\
\hline & pg0310 & gross income from public pensions \\
\hline & pg0510 & gross income from unemployment benefits \\
\hline & hg0510 & gross income from private business other than self-employment \\
\hline & hg0410 & gross income from financial investments \\
\hline & hg0310 & gross rental income from real estate property \\
\hline & hg0610 & gross income from other income sources \\
\hline & hg0110 & gross income from regular social transfers \\
\hline & pne0200 & Gross income from emplyment \\
\hline & pne0800 & Gross income from Other job \\
\hline & pne0300 & Gross income from business activities \\
\hline & pxg0600 & Net income (including all incomes) \\
\hline \multicolumn{2}{|c|}{ Socio-demographic characteristics (HHM levє ra0300 } & age \\
\hline & $\mathrm{ra0200}$ & gender \\
\hline & $\mathrm{ra0100}$ & relationship to reference person \\
\hline & $\mathrm{ra0400}$ & country of birth \\
\hline & pa0100 & marital status \\
\hline & pa0200 & highest level of education completed \\
\hline \multirow[t]{5}{*}{ Assets - housing collateral (HH level) } & hb0900 / hb2801 & current value of the collateral \\
\hline & hb0800 & property value at the time of its acquisition \\
\hline & hb2501 & other property type \\
\hline & hb2801 & other property current value \\
\hline & hb2701 & $\%$ of the property belonging to household \\
\hline \multirow[t]{6}{*}{ Assets - liquid financial assets (HH level) } & hd1110 & value of sight accounts \\
\hline & hd1210 & value of saving accounts \\
\hline & hd1330 & market value of mutual funds - all funds together \\
\hline & hd1420 & market value of bonds \\
\hline & hd1510 & value of publicly traded shares \\
\hline & hd1620 & value of additional assets in managed accounts \\
\hline \multirow[t]{6}{*}{ Liabilities - mortgage debt (HH level) } & hb1010 / hb3011 & Number of mortgages \\
\hline & hb1301 / hb33011 & Year when mortgage was taken or refinanced \\
\hline & hb1401 / hb34011 & initial amount borrowed \\
\hline & hb1601 / hb36011 & length of the loan at the time of borrowing/refinancing \\
\hline & hb1901 / hb39011 & current interes rate of the loan \\
\hline & hb2001 / hb40011 & monthly amount of payment made on loan \\
\hline \multirow[t]{13}{*}{ Consumer loans and other debt (HH level) } & hc0200 & household has credit line or overdraft \\
\hline & hc0300 & household has a credit card \\
\hline & hc0220 & amount of outstanding credit line/overdraft balance \\
\hline & hc0320 & amount of outstanding credit cards balance \\
\hline & hc0110 & monthly leasing payments \\
\hline & hc0601 & amount initially borrowed \\
\hline & hc0701 & intitial length of the loan \\
\hline & hc0801 & outstanding balance of loan \\
\hline & hc0901 & current interest rate of loan \\
\hline & hc1001 & monthly payment on loan \\
\hline & hc1100 & total amount owed for additional non-collateralised loans \\
\hline & hc1200 & monthly payment on additional non-collateralised loans \\
\hline & hc0361 & private loan outstanding amount \\
\hline
\end{tabular}


Table A2. Descriptive Statistics and Definitions of Lending Standards from HFCS

\section{Panel A}

\begin{tabular}{|lr|}
\hline Data & Value \\
\hline No. of HHs in whole population & $1,852,059$ \\
No. of borrowing HHs in HFCS sample of 2015-2017 & 92 \\
No. of HHMs in borrowing HFCS sample of 2015-2017 & 155 \\
No. of total borrowing HHs represented by the HFCS sample of $2015-2017$ & 111,291 \\
Borrowing HHM/HH ratio & 1.7 \\
Average LTV (weighted by volume of the loan and HH weight) & $\mathbf{7 7 \%}$ \\
Share of new loans with LTV>80\% & $55 \%$ \\
Average DSTI (weighted by volume of the loan and HH weight) & $\mathbf{4 3 \%}$ \\
Share of new loans with DSTI>80\% & $14 \%$ \\
Average DTI (weighted by volume of the loan and HH weight) & $\mathbf{4 . 9}$ \\
Share of new loans with DTI>8 & $15 \%$ \\
\hline Source: HFCS and authors' calculations & \\
Note: LTV, DSTI and DTI per national regulatory definitions & \\
\hline
\end{tabular}

\section{Panel B}

\begin{tabular}{|c|c|c|}
\hline Variable & Formula & Details \\
\hline LTV & $\begin{array}{l}\text { LTV } V_{i} \\
=\frac{\text { First mortgage amount }}{\text { Value of } H M R_{i}} \\
+I(\text { Same collateral }) \\
* \frac{\text { FV of second mortgage }}{{\text { Value of } H M R_{i}}}\end{array}$ & $\begin{array}{l}\text { First mortgage amount } \\
\text { Value of HMR }_{i}=h b 1401 \\
\begin{aligned} \text { FV of second mortgage } \\
$\[ \]$ \\
$\[ \begin{aligned} \\
\end{aligned} \]$ \\
$\[ \]$ \\
$\[ \left(1+h b 1402 *(1+h b 1902)^{(h b 1301-h b 1302)}+h b 2002\right. \]$ \\
h b 1902) \frac{\left((1+h b 1902)^{(h b 1301-h b 1302)}-1\right)}{h b 1902}\end{aligned}\end{array}$ \\
\hline DSTI & $\begin{array}{l}\text { DSTI }_{i} \\
=\frac{\text { Debt payments }_{i}}{\text { Income }_{i}-\text { Subsistence min }}\end{array}$ & $\begin{array}{l}\text { Debt payments }_{i} \\
\qquad \begin{aligned} \text { hb } 1401 *\left(\frac{h b 1901}{1-(1+h b 1901)^{-h b 1601 * 12}}\right) *(1 \\
+\end{aligned} \\
\qquad \text { Income }_{i}={\text { pxg } 0600_{1}+\text { pxg0600 }}_{2} \\
\text { Subsistence minimum } \\
=\left\{\begin{array}{l}198.09+90.42 * \# \text { children if \#debtors }=1 \\
336.28+90.42 * \# \text { children if \#debtors }=2\end{array}\right.\end{array}$ \\
\hline$\overline{D T I}$ & $D T I_{i}=\frac{\text { Total debt }_{i}}{\text { Income }_{i} * 12}$ & $\begin{aligned} \text { Total debt }_{i}= & h b 1401+F V \text { of second mortgage }+ \text { hc0220 } \\
& +h c 0320+h c 0801\end{aligned}$ \\
\hline
\end{tabular}

Note: "First mortgage" is defined as the mortgage taken during the period between 2015 and 2017. If several mortgages are taken during this period, they are summed up. Mortgages granted before this period are taken into calculation as "other debt." If necessary, data are rearranged according to these rules. 
Table A3. Macro Data

\begin{tabular}{|c|c|c|}
\hline Category & Variable ID & Variable description \\
\hline \multirow[t]{20}{*}{ Supply side } & delta & Depreciation rate of capital \\
\hline & $F_{-} L$ & Total employment in EA12 \\
\hline & F_LPROD & Labour productivity in EA12 \\
\hline & F_M & Imports of goods and services in EA12 \\
\hline & F_Y & Gross domestic product in EA12 \\
\hline & $\mathrm{K}$ & Capital stock, whole economy \\
\hline & K_priv & Capital stock, private \\
\hline & $\mathrm{L}$ & Employment, total \\
\hline & L_EM & Employees, total \\
\hline & L_POT & Potential employment \\
\hline & L_POT_ILO & Potential employment, ILO concept \\
\hline & LF & Labour force, ILO concept \\
\hline & NAIRU_ILO & NAIRU, ILO concept \\
\hline & TFP & Total factor productivity \\
\hline & U_GAP & Unemployment gap \\
\hline & UN & Unemployment \\
\hline & UR & Unemployment rate \\
\hline & WAP & Working age population \\
\hline & Y_GAP & Output gap \\
\hline & Y_POT & Potential output \\
\hline \multirow[t]{19}{*}{ Demand side } & $\mathrm{A}$ & Wealth \\
\hline & adj_pension & Adjustment for the change in pension entitlements \\
\hline & CONS & Private consumption \\
\hline & $\mathrm{D}$ & Government consolidated gross debt \\
\hline & DISP_Y & Households disposable income \\
\hline & G & Government consumption \\
\hline & ChErr & Statistical discrepancy \\
\hline & CHS & Changes in inventories + acquisitions less disposals of valuables \\
\hline & I & Investment, total \\
\hline & I_gov & Investment, government \\
\hline & I_priv & Investment, private \\
\hline & I_nonresid & Investment, private nonresidential \\
\hline & I_resid & Investment, private residential (dwellings) \\
\hline & M & Imports of goods and services \\
\hline & NFA & Net foreign assets \\
\hline & Sratio & Saving ratio \\
\hline & WDR & World demand indicator \\
\hline & $\mathrm{X}$ & Exports of goods and services \\
\hline & $\mathrm{Y}$ & Gross domestic product \\
\hline
\end{tabular}




\begin{tabular}{|c|c|c|}
\hline Prices & $\begin{array}{l}\text { CI_CE_PH } \\
\text { CMD } \\
\text { CMD_NRU } \\
\text { CMD_NRU_exEENM } \\
\text { CXD } \\
\text { CXD_exEENX } \\
\text { DIFF_LPROD } \\
\text { EENM } \\
\text { EENX } \\
\text { HEG } \\
\text { HEW } \\
\text { HEX } \\
\text { HEXEX } \\
\text { HEXEX_admin } \\
\text { HFW } \\
\text { HICP } \\
\text { HIF } \\
\text { i_HH } \\
\text { i_HHP_LT } \\
\text { i_HHP_ST } \\
\text { i_NFC_LT } \\
\text { i_NFC_ST } \\
\text { i_nom_10Y } \\
\text { i_nom_1Y } \\
\text { i_nom_3m } \\
\text { IIR } \\
\text { LPROD } \\
\text { P_OIL } \\
\text { PC } \\
\text { PG } \\
\text { PI } \\
\text { PM } \\
\text { PM_E } \\
\text { PM_exE } \\
\text { PX } \\
\text { PY } \\
\text { RER_M } \\
\text { RER_X } \\
\text { RU_rCMD } \\
\text { RX_USDEUR } \\
\text { TTN_food } \\
\text { ULC } \\
\text { W } \\
\text { W_E } \\
\text { W_gov } \\
\text { w_HHP_LT } \\
\text { w_HHP_ST } \\
\text { w_NFC_LT } \\
\text { W_NFC_ST } \\
\text { W_priv } \\
\text { _H }\end{array}$ & $\begin{array}{l}\text { Compensation per employee } \\
\text { Competitors prices on the import side in } € \\
\text { Competitors prices on the import side in } € \text { (excl. Russia) } \\
\text { Competitors prices on the import side in } € \text { (excl. Russia and EENM) } \\
\text { Competitors prices on the export side in } € \\
\text { Competitors prices on the export side in } € \text { (excl. EENX) } \\
\text { Labour productivity differential } \\
\text { Nominal effective exchange rate on the import side } \\
\text { Nominal effective exchange rate on the export side } \\
\text { HICP energy } \\
\text { Energy weights } \\
\text { HICP excluding energy } \\
\text { HICP excluding energy and food } \\
\text { HICP excluding energy and food - administrative prices } \\
\text { Food weights } \\
\text { HICP } \\
\text { HICP food } \\
\text { Composite interest rate (for consumption) } \\
\text { Households long term interest rates } \\
\text { Households short term interest rates } \\
\text { NFC long term interest rates } \\
\text { NFC short term interest rates } \\
\text { SK 10Y bonds } \\
\text { 1Y interest rate } \\
\text { 3M EURIBOR } \\
\text { Composite interest rate (for investment) } \\
\text { Labour productivity } \\
\text { Oil price in } \$ \\
\text { Private consumption deflator } \\
\text { Government consumption deflator } \\
\text { Investment deflator } \\
\text { Import deflator } \\
\text { Import deflator, energy } \\
\text { Import deflator, non-energy } \\
\text { Export deflator } \\
\text { GDP deflator } \\
\text { = PY/(PM_exE) } \\
\text { = PX/CXD } \\
\text { Competitors prices on the import side - Russia } \\
\text { Exchange rate USD/EUR } \\
\text { Index of food commodity prices } \\
\text { Unit labour costs } \\
\text { Quarterly average wage in the economy } \\
\text { Import deflator, energy weights } \\
\text { Quarterly average wage in government sector } \\
\text { Households long term interest rates, weight } \\
\text { Households short term interest rates, weight } \\
\text { NFC long term interest rates, weight } \\
\text { NFC short term interest rates, weight } \\
\text { Quarterly average wage in private sector }\end{array}$ \\
\hline
\end{tabular}




\section{Box A1: Macroeconomic and Satellite Modules}

\section{The structural error correction model}

The central three-year adverse scenario was produced using the structural ECM of the NBS for official medium-term forecasts. The model is a standard medium-size econometric model of a small open economy, employing backward-looking expectations. Its formulation ensures that certain economic relationships hold in the long run (steady state output is determined by the supply side), while allowing for short-term fluctuations in actual economic output (derived from the demand side).

The model consists of three main blocks: the supply side, the demand side, and the price block. Figure A1 provides a bird's-eye view of the model structure.

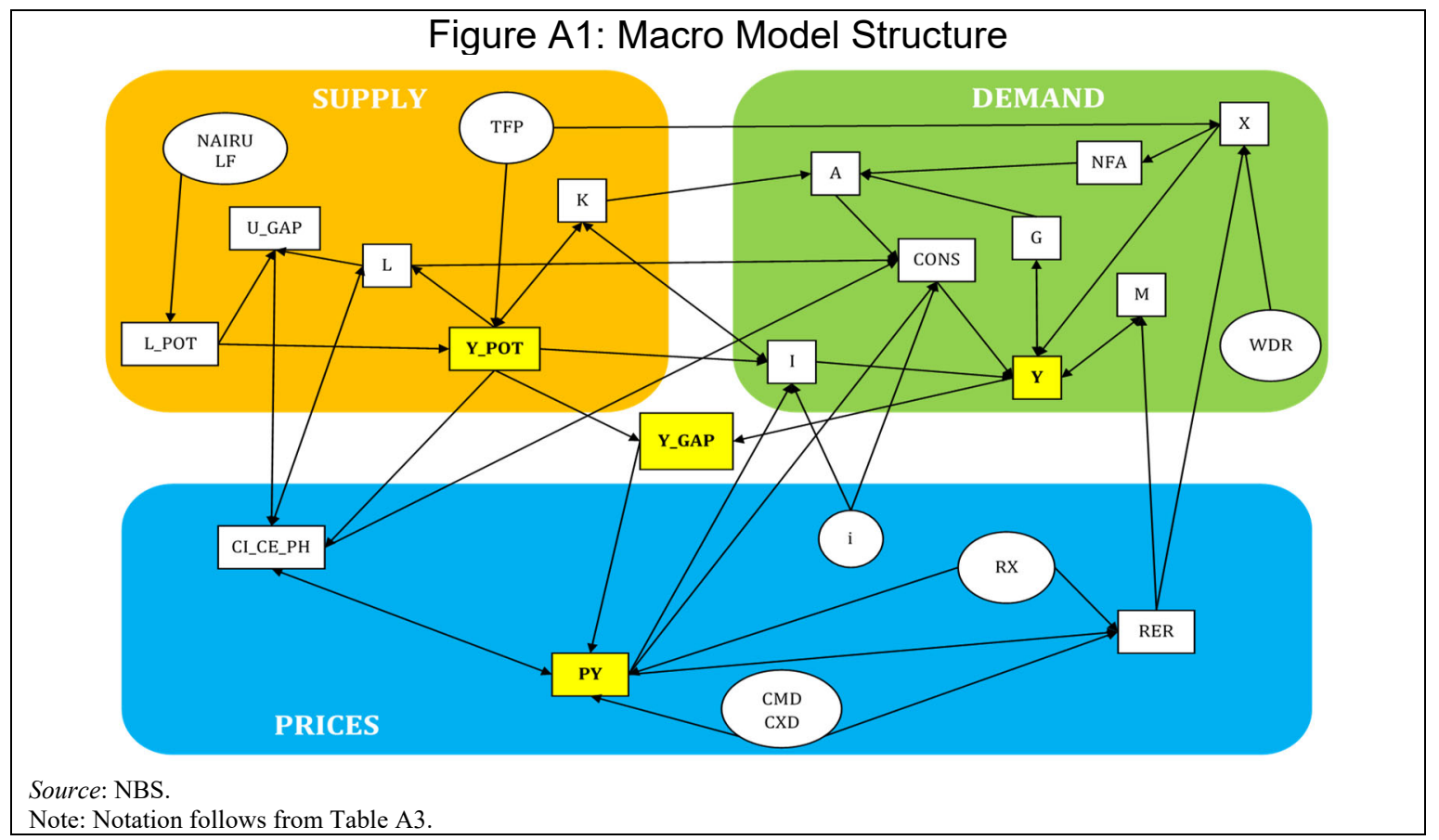

The model was introduced by Rel'ovský and Široká (2009). It has been repeatedly reestimated, updated, and enlarged. While the current version of the model captures prices and interest rates in greater detail, it maintains its original logic and architecture.

One satellite model estimates the development of the annual absolute changes of the outstanding volume of total retail loans using a set of 9 VEC models. In each VEC model, three explanatory variables are used from the following set of macroeconomic variables: (1) nominal or real GDP; (2) level and growth in HICP; (3) unemployment ratio; (4) 3M EURIBOR; (4) property or flat prices, and (5) the five or ten-year spread between Slovak and German government bond yields. The absolute changes of retail loans, GDP, and the Harmonised Index of Consumer Prices (HICP) enter the models in a natural logarithm

$$
\begin{aligned}
& \Delta \ln \left(R L_{\text {aach }}\right)_{t}=-\alpha\left(R L_{\text {aach }_{t-1}}-\beta_{0}-\beta_{1} M V_{1, t-1}-\beta_{2} M V_{2, t-1}-\beta_{3} M V_{3, t-1}\right)+ \\
& \text { short term dynamics }+\varepsilon_{t},
\end{aligned}
$$


where $R L_{\text {aach }}$ stands for the annual absolute change of retail loans, and $M V_{i}$ is the explanatory macro variable used. The average of the estimated development of the outstanding amount of retail loans by the nine models is then used. The volume of retail loans is transformed to the volume of retail housing loans by using the assumption that the share of housing loans in total retail loans is unchanged and the same as in the latest period observed.

Another satellite model estimates the volume of nonperforming housing loans. The Bayesian Model Averaging (BMA) model is used for the estimation. The equations estimated using the least squares method have the form

$$
\Delta N P L_{t}=\alpha+\rho_{1} \Delta N P L_{t-1}+\cdots+\rho_{p} \Delta N P L_{t-p}+\sum_{j=1}^{K}\left(\beta_{1}^{j} X_{t-1}^{j}+\cdots+\beta_{q}^{j} X_{t-q}^{j}\right)+\varepsilon_{t}
$$

where $\triangle N P L$ is the quarterly change of the nonperforming loan ratio and $X$ contains a set of explanatory variables. The maximum number of lags is 4 , with the optimal length of lags being chosen using the Bayesian information criterion. At any one time, two to four explanatory variables are included in the equations. The variables used include real and nominal GDP in absolute volumes and growth rates, inflation as index or annual change, unemployment rate, and property and flat prices. In the end, the estimated equations are weighted using the Bayesian information criterion.

\section{Box A2: Micro Modules: Generating Probabilities of Staying Employed/Employment Status and Counterfactual New Mortgage Lending \\ Generating Probabilities of Staying Employed}

Logit equation for the probability of staying employed of household members:

$$
P E_{i}=\frac{1}{1+e^{-\left(\beta_{0}+\sum_{k} \beta_{k} x_{k}^{i}\right)}}
$$

Table A4. Estimated Coefficient of the Logit Model

\begin{tabular}{ll}
\hline Intercept & -0.323 \\
Education (higher $=2$, secondary $=1$, primary $=0)$ & $2.039^{\star * *}$ \\
Marital status (single $=1$ ) & $-0.638^{\star * *}$ \\
Gender (male = 1, female $=0)$ & 0.034 \\
Age (years) & 0.008 \\
Nationality (foreign= 1) & -0.797 \\
\hline Total number of observations & 2322 \\
AUROC & 0.75 \\
\hline
\end{tabular}

Source: Authors' calculations based on HFCS data.

Note: The model is estimated based on HFCS data from 2016. Data used covers the full HFCS sample, not only clients with a mortgage debt.

Technically, the employment status of an HHM is determined in the following way. 
Each HHM in the sample is assigned the HFCS weight of the HH to which the member belongs, normalized across members. The initial employment rate in this sample (obtained by multiplying the employment status $(1=$ employed $)$ by the normalized weight of each HHM and summing up across members) is decreased in every period of the adverse scenario by the positive change (increase) in the unemployment rate from the macro module. In parallel, another sample implied that the employment ratio is computed using the same sample weights and members, but also the probabilities of staying employed based on the logit parameters. The squared difference between these two implied employment ratios is then minimized to solve for the period-by-period value of the logit intercept parameter that ensures the full consistency between them. The adjusted logit intercept parameters are then used to calculate the joint probability of staying employed of the household members, which is then used to compute the probability of default of the household (see Box A3).

The interpretation of this technical approach is that when the probability of staying employed decreases for a given surveyed HHM (because of worsening macroeconomic conditions), a number of HHMs proportionate to the weight of the surveyed member become unemployed. For example, the HHM belonging to the HH with an HFCS weight of 1,624 is assumed to represent 1,624 other members with similar sociodemographic characteristics. For example, when this HHM's probability of staying employed decreases from 0.99 to 0.97 between Q2 and Q3 of the adverse horizon, we interpret that in the whole population, about 30 HHMs $((0.99-0.97) \times 1,624)$ with similar characteristics become unemployed.

\section{Generating counterfactual new mortgage lending}

The new lending in each quarter $t=1, \ldots, 20$ of the five-year simulation horizon is simulated based on two conditions that determine the following:

1. Allocation of new loans: by increasing the HFCS weight of each household in order to match the period-by-period simulated amount of new lending in the whole population coming from the credit satellite of the macro module. The adjustment in the HFCS weight is interpreted as equivalent to new households (with similar sociodemographic characteristics as those existing in the HFCS sample) entering the mortgage market and being allocated new loans.

2. New loan amount: by calculating the amount of a simulated new mortgage granted to a particular household in quarter $t$ such that values of DTI/DSTI and LTV of that household remain the same as in the original sample, adjusting for changes in the income of the HHMs and in house prices.

The weight $\left(W_{h, t}\right)$ of household $h \in \mathcal{H}$ in quarter $t$ is gradually increased by the increment $w_{h, i}$ in each quarter $i$, that is

$$
W_{h, t}=\sum_{i=1}^{t} w_{h, i} .
$$

The calculation of this increment is based on the original weight of the household $h$ in the HFCS sample, which is proportionately rescaled to the change in the overall new mortgage 
lending (from the satellite model) in that particular quarter (total new lending $_{t}$ ) compared to the total new lending in the HFCS sample in 2015-17 (total new lending ${ }^{H F C S}$ ), that is

$$
w_{h, t}=w_{h}^{H F C S} \times \frac{\text { total new lending }}{\text { total new lending } H F C S} \times \frac{\text { income }_{1, h}^{H F C S}+\text { income }_{2, h}^{H F C S}}{\text { income }_{1, h, t}+\text { income }_{2, h, t}} .
$$

While the new lending adjustment is applied in the exuberant period, during the adverse scenario the recalculation of the weights needs to also account for the diminishing effect of declining incomes on the value of individual new loans.

The amount of the new mortgage $\left(L_{h, 0}^{t}\right)$ granted to household $h \in \mathcal{H}$ (where $\mathcal{H}$ refers to the set of household with mortgage in the sample) in quarter $t=1, \ldots, 20$, is based on the amount of mortgage granted during 2015-17 in the HFCS sample $\left(L_{h, 0}^{H F C S}\right)$, adjusted for decline of income of the HHMs, if relevant, that is

$$
L_{h, 0}^{t}=L_{h, 0}^{H F C S} \times \frac{\text { income }_{1, h, t}+\text { income }_{2, h, t}}{\text { income }_{1, h}^{H F C S}+\text { income }_{2, h}^{H F C S}} .
$$

The income decline of the HHMs remaining employed depends on the business cycle sensitivity of the economic sector where the HHM is employed (Table A5).

The value of the real estate collateral is analogously rescaled to keep the same LTV.

These calculations refer to the no-policy scenario. In the scenario where policy measures are introduced, the amount of new lending granted to individual households might be further decreased in order to reflect the impact of the limits imposed on the LTV, DTI, and DSTI. We assume that loans affected by the measures are still granted, albeit with a lower volume. In turn, this adjustment is then used to calculate the effect of policy interventions on the total new lending.

Table A5. Sensitivity of Economic Segments to Business Cycle

\begin{tabular}{cc}
\hline & Transport \\
& Electronics industry \\
Real estate activities & Trade \\
Most sensitive & Agriculture \\
& Food manufacturing \\
& Recreation \\
& Construction \\
& Machine industry \\
& Textile industry \\
\hline Less sensitive & Chemical industry \\
& Services \\
& Telecommunications \\
& Utilities \\
\hline Non-sensitive & Forestry and logging \\
& Materials \\
& Mining and quarrying \\
& General government \\
\hline
\end{tabular}

Source: NBS, Annexes to the Analysis of the Slovak Financial Sector, 2018 (NACE based) 


\section{Box A3: Rule for Default Detection and Simulation of PD and LGD}

For each representative household, the new loan is assigned a maximum of persons (algorithm favoring the younger and higher earners out of the income earning HHMs).

$P U_{h, i, t}$ denotes the probability that HHM $i=1,2$ in household $h \in \mathcal{H}$ becomes unemployed during the period between $t-1$ and $t$, where $t=1, \ldots, 20$. This probability is implied by the probability $P E_{h, i, t}$ of HHM $i$ in household $h \in \mathcal{H}$ staying employed (determined in the logit model) as follows

$$
P U_{h, i, t}=P E_{h, i, t}-P E_{h, i, t-1}
$$

There are four possible situations that might occur based on which of the HHMs is likely to become unemployed. These situations are summarized in the following table. The income of household members who become unemployed is assumed to be $b$-times their original income, where

$$
b_{t}=\left\{\begin{array}{c}
0.75 \text { during the first six months (unemployment benefit), } \\
0 \text { later. }
\end{array}\right.
$$

\begin{tabular}{|c|c|c|}
\hline Joint probability of occurrence and & $\mathrm{P}_{2}$ stays employed & $\mathrm{P}_{2}$ becomes unemployed \\
\hline$P_{1}$ stays employed & $\begin{array}{lr}\text { Prob(s1): } & \left(1-P U_{h, 1, t}\right) \times\left(1-P U_{h, 2, t}\right) \\
\text { Income: } & \text { income } 1+\text { income } 2\end{array}$ & $\begin{array}{ll}\text { Prob(s3): } & \left(1-P U_{h, 1, t}\right) \times P U_{h, 2, t} \\
\text { Income: } & \text { income } 1+b_{t} \times \text { income } 2\end{array}$ \\
\hline $\mathrm{P}_{1}$ becomes unemployed & $\begin{array}{ll}\text { Prob(s2): } & P U_{h, 1, t} \times\left(1-P U_{h, 2, t}\right) \\
\text { Income: } & b_{t} \times \text { income }_{1}+\text { income }_{2}\end{array}$ & $\begin{array}{ll}\text { Prob(s4): } & P U_{h, 1, t} \times P U_{h, 2, t} \\
\text { Income: } & b_{t} \times\left(\text { income }_{1}+\text { income }_{2}\right)\end{array}$ \\
\hline
\end{tabular}

Simulated Combinations of Employment and Income of HHMs

Source: Authors' calculations.

For each situation $s_{j}(j=1,2,3,4)$, an illiquidity gap of the household $h \in \mathcal{H}$ is defined as

$$
\operatorname{Gap}_{h, t}\left(s_{j}\right)=\left(\operatorname{Income}_{h, t}\left(s_{j}\right)-\text { Total payments }_{h}-\text { Subsistence minimum }_{h}\right)^{+} .
$$

The default is assumed to occur if the drawdown of households' financial assets $\left(F A_{h}\right)$ is not sufficient to cover illiquidity gaps during at least 18 months. Hence, the indicator of default is calculated as:

$$
D_{h}\left(s_{j}\right)=\left\{\begin{array}{l}
1 \text { if } \sum_{t=1}^{18} \operatorname{Gap}_{h, t}\left(s_{j}\right)>F A_{h}, \\
0 \text { if } \sum_{t=1}^{18} \operatorname{Gap}_{h, t}\left(s_{j}\right) \leq F A_{h} .
\end{array}\right.
$$

Probability of default $\left(\boldsymbol{P} \boldsymbol{D}_{\boldsymbol{h},(t-1, t)}\right)$ of household $h$ is calculated as

$$
P D_{h,(t-1, t)}=\sum_{j=1}^{4} \operatorname{Prob}\left(s_{j}\right) \times D_{h}\left(s_{j}\right),
$$


where $\operatorname{Prob}\left(s_{j}\right)$ is the probability of occurrence of situation $s_{j}$.

The loss given default $\boldsymbol{L} \boldsymbol{G} \boldsymbol{D}_{h, t}$ of household $h \in \mathcal{H}$ at time of default $(t)$ is calculated based on the difference between the outstanding amount of the loan at time $t(L h, t)$ and value of the real estate collateralizing the loan at the end of the adverse period $\left(R E_{T}\right)$ (since we assume that the collateral is not realized immediately at default but only later, hence its value might be further impaired) plus the fixed cost of foreclosure

$$
L G D_{h, t}=\left(\frac{L_{h, t}-R E_{h, T}}{L_{h, t}}\right)^{+}+0.1 \times L_{h, t} .
$$

The value of the real estate at time $T$ is calculated based on the decline in property prices between the moment of loan origination $\left(P_{O}\right)$ and the end of the adverse period $\left(P_{T}\right)$ applied to the value of the real estate collateral at time of loan origination

$$
R E_{h, T}=R E_{h, O} \times \frac{P_{T}}{P_{O}}=\frac{L_{h, O}}{L T V_{h}} \times \frac{P_{T}}{P_{O}} .
$$

\section{Box A4: Key Output Variables for Determining the Resilience of Households and Bank Losses on Mortgage Portfolios}

Portfolio aggregated probability of default at time $T$ (end of adverse horizon)

$$
P D_{T}=\sum_{t=1}^{T} \sum_{\mathrm{h} \in \mathrm{H}} P D_{h,(t-1, t)} \times W_{h, t},
$$

where $P D_{h,(t-1, t)}$ is the probability that household $h \in \mathcal{H}$ defaults on its debt in the period between $t-1$ and $t$ and $W_{h, t}$, is the weight of the HH in the HFCS at time $t$. Based on this calculation, the PD is net of already defaulted loans in the sample and is therefore driven only by the adverse scenario. This also applies to all the following variables.

Total cumulative amount of defaulted (nonperforming) loans at time $T$ is

$$
N P L_{T}=\sum_{t=1}^{T} \sum_{\mathrm{h} \in \mathrm{H}} P D_{h,(t-1, t)} \times L_{h, t} \times W_{h, t},
$$

where $L_{h, t}$ is the outstanding amount of loan of household $h \in \mathcal{H}$ at time $t$.

\section{Total cumulative expected loss at time $T$}

$$
E L_{T}=\sum_{t=1}^{T} \sum_{\mathrm{h} \in \mathrm{H}} P D_{h,(t-1, t)} \times L G D_{h, t} \times L_{h, t} \times W_{h, t}
$$

where $L G D_{h, t}$ is loss given default of mortgage debt of household $h \in \mathcal{H}$ at time $t$. 
Cumulative portfolio aggregated NPL ratio is calculated as

$$
N P L \operatorname{ratio}_{T}=\frac{N P L_{T}}{\text { Volume }_{T}}
$$

Portfolio aggregated loss given default at time $T$ is calculated as

$$
L G D_{T}=\frac{E L_{T}}{N P L_{T}}
$$

Portfolio aggregated loss rate at time $T$ is calculated as

$$
L R_{T}=\frac{E L_{T}}{\text { Volume }_{T}}
$$

Total volume of outstanding loans at time $T$ granted since the beginning of the simulation horizon is

$$
L_{T}=\sum_{t=1}^{T} \sum_{\mathrm{h} \in \mathrm{H}} L_{h, t} \times W_{h, t},
$$

All computations are repeated over 10,000 macro (unemployment) adverse scenarios.

Table A6. Common Assumptions across Adverse Scenarios

\begin{tabular}{|lcl|}
\hline Variable & & Assumption \\
\hline Adverse period (stress horizon) & 3 years & \\
New loan simulation period & 5 years & \\
Aggregate unemployment ratio & $5 \%$ & gradual (cumulative) increase over adverse period \\
Aggregate mortgage credit growth & $2.3 \%$ & gradual (annual) decrease over adverse period \\
Change in property prices (collateral value) & $30 \%$ & gradual (cumulative) decrease over adverse period \\
Change in income if unemployed & $25 \%$ & decrease (cumulative) during the first 2 quarters \\
& & no income thereafter \\
Change in income if employed & $20 \%$ & decrease (cumulative) during the first 5 quarters if employed in sensitive sector \\
& $10 \%$ & decrease (cumulative) during the first 5 quarters if employed in less sensitive sector \\
& $5 \%$ & decrease (cumulative) during the first 5 quarters if employed in non-sensitive sector \\
Max borrower age & 70 years & maximum borrower age until the loan maturity can be extended \\
Fixed cost of foreclosure & $10 \%$ & of the outstanding amount of the defauled mortgage loan \\
\hline Source: Authors calculations & & \\
\hline
\end{tabular}




\section{Annex 3: Reported versus Imputed Current House Price Values}

The model in this paper follows the original approach of GP 2017 by using the households' self-assessed value of their real estate property as of the survey date as one of its inputs. This reported value might deviate to an extent from the real estate's actual market value for various reasons: households may not have all available information at their disposal and may not actually have approached the market around the time of the survey date for the purpose of selling their houses in many cases, hence rendering their reported house value estimate an approximation.

One benchmark to assess the adequacy of the self-reported value can be derived by indexing the households' real estate value from the time of acquisition to the present based on aggregate house price developments. Figure A2 shows the distribution of self-reported values in comparison to a house value distribution that was obtained by indexing their value from origination up to the present. The median deviation between the reported and imputed house price values equals about 2 percent. The $25^{\text {th }}$ and $75^{\text {th }}$ percentiles equal -22 percent and +32 percent, respectively.

The imputation is itself subject to some caveats. For example, the imputation was conducted based on an aggregate house price index for Slovakia, without any differentiation into subregions whose house price dynamics may behave differently from the aggregate.

This robustness check suggests that our model results are overall robust to a misestimation of households' house values. At the same time, it suggests that accounting for this uncertainty in future model applications that rely on current house values will be beneficial and will deserve more dedicated analysis.

Figure A2: Reported versus Imputed (Approximate) House Values as of the Survey Date

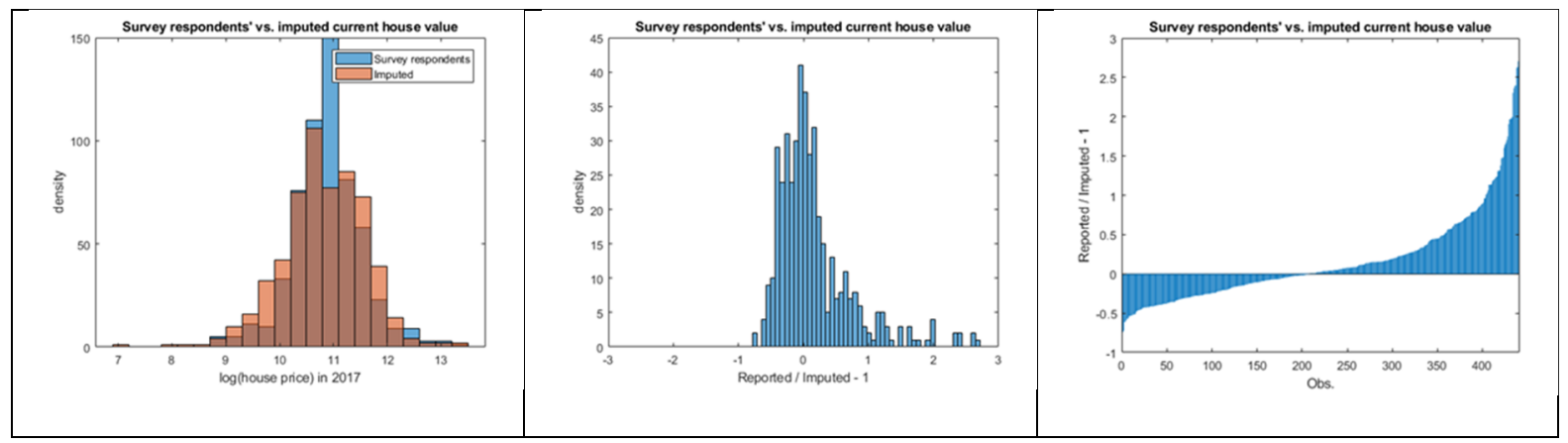

